\title{
"Trophy Architects" and design as rent-seeking: Quantifying deadweight losses in a tightly regulated office market
}

\author{
Paul C. Cheshire \\ London School of Economics \& Centre for Economic Performance \\ p.cheshire@lse.ac.uk \\ and \\ Gerard H. Dericks \\ Oxford Brookes University \\ gdericks@brookes.ac.uk
}

This version: July 31 2019

\section{Acknowledgements}

*The authors would like to thank Jonathan Bradley, Christina Burbanks, Phil Hammond, Joseph Kelly, Theresa Keogh, Hannah Lakey, Gavin Murgatroyd, David Stothard, Stephen Waterman, City of London Planning Department, Estates Gazette, Gardiner \& Theobald, Greater London Authority, Property Market Analysis, and Real Capital Analytics. We would also like to thank colleagues Gabriel Ahlfeldt, Kerwin Datu, Steve Gibbons, Christian Hilber, and Hans Koster, and participants in the Urban Economics Association sessions at the European Regional Science Association's Congress in Palermo in August 2013 and at the 61 ${ }^{\text {st }}$ Annual North American Meetings of the Regional Science Association International in Washington D.C. in November 2014, where earlier versions of this paper were presented. Excellent research assistance was provided by Leon De-Graaf and Yu-Jen Chen. The authors are responsible for all errors and interpretation. 


\begin{abstract}
Britain tightly restricts the supply of office space creating substantial economic rents, but its development restrictions are politically administered and therefore gameable, inducing rentseeking activity. We find that 'trophy architects' (TAs) - prior winners of a lifetime achievement award - obtain more space on a given site apparently by signalling iconic design. Analysis of 2,039 office buildings shows TAs build 14 stories taller, increasing a representative site value by 152 percent. We argue this premium is compensation for the extra costs, risks and delays of using a TA to game the planning system; and therefore an indirect measure of deadweight rent-seeking losses.
\end{abstract}

JEL classification: H11; K25; R33.

Keywords: Land use regulation, regulatory costs, rent-seeking, office markets, trophy architects, quasi-natural experiment

Corresponding author: Paul Cheshire, Dept. of Geography \& Environment, London School of Economics, Houghton St, London WC2A 2AE, U.K., fax +44 (0)20 7955 7412, phone: +44 (0)20 7955 7586, p.cheshire@lse.ac.uk. 
[the Minister]... “will only approve skyscrapers of exceptional design. For a building of this size to be acceptable, the quality of its design is critical... the proposed tower is of highest architectural quality” (Deputy Prime Minister of the United Kingdom, John Prescott, 2003)

Why does the incidence of tall buildings vary so substantially across the world's cities - even cities of similar size and prosperity? The answer appears to be largely regulation. It is also notable that the largest buildings in some cities are designed by architects we define here as ‘Trophy Architects' (TAs) whereas in others they are not. TAs we identify on the basis of having won one of architecture's three major lifetime achievement awards, so certifying their outstanding reputations to the world at large. This paper investigates what role such architects may play in the extreme case of London, a city with particularly restrictive regulation constraining the supply of office space, making it hard to construct tall buildings and so generating substantial potential rents, but with a regulatory system where decisions are as much politically as rule determined.

Our results suggest that the primary function of these TAs in London is as rent-seeking agents. In so far as the evidence supports this conclusion we can cast light on what has long proved to be a kind of 'dark matter' for public economics; credible quantitative estimates of the costs of rent-seeking. Surprisingly, despite the ubiquity and relative stringency of land market regulation worldwide, we are aware of only one previous attempt to quantify rentseeking costs in this context (Antwi and Adams, 2003). As well as contributing to the growing literature on land use regulation and that on rent-seeking, this paper also adds to the emerging literature on the 'vertical city' or tall buildings, to our understanding of the extent and sources of any premium for star architect design and the relatively small body of studies 
"Trophy Architects" and design as rent-seeking:

Quantifying deadweight losses in a tightly regulated office market

of commercial real estate using sales data from observed transactions for individual buildings.

The emerging vertical city literature has found increasingly persuasive evidence of vertical agglomeration economies as well as price premia (Koster et al., 2014 or Liu et al., 2018). In addition a recent contribution (Ahlfeldt and McMillen, 2019) has documented the role played by the supply side as well as the demand side in the incidence of tall office compared to residential buildings: they have different costs of construction.

As with previous studies we find a significant relationship between architectural design and economic outcomes (Asabere et al, 1989; Fuerst et al, 2011; Gat, 1998; Hough and Kratz, 1983; Nase et al, 2013; Vandell and Lane, 1989), measuring 'economic outcomes' as the price paid for space. Buildings designed by our TAs do command a small but significant premium suggesting that there is a productivity advantage associated with their buildings. This is dwarfed, however, by their capacity to get additional floors on a given site when regulations do not absolutely forbid this. Abstracting from this design premium, we are then able to estimate the increase in site value attributable only to the extra floorspace, the signalling power of their reputations appears to allow.

Tall buildings command a premium - often substantially greater than the cost of making them taller (Glaeser et al, 2005; Cheshire and Hilber, 2008). The number of tall buildings per capita varies remarkably in cities around the world. Elementary urban economics leads one to expect there to be more in big cities as agglomeration economies and land prices increase with city size, especially where such cities, like Hong Kong, are crowded onto islands; or are constrained by growth boundaries. But while the New York metro area is more than twice as 
"Trophy Architects" and design as rent-seeking:

Quantifying deadweight losses in a tightly regulated office market

populous as Hong Kong, Hong Kong has eight times as many skyscrapers 1 - buildings over 100 meters tall - per person than New York. A medium sized, provincial city such as Brisbane, Australia, has six times as many skyscrapers per person as Paris and eight times as many as London. Topping all cities in the tall buildings league table is a real surprise:

Benidorm in Spain. This small tourist city has some 71,000 residents but 1.15 times as many skyscrapers and nearly 17 times as many high rise buildings - buildings over 35 meters - per resident as New York.

In both these leagues, London, despite its size and prosperity and one of the most tightly constraining growth boundaries in the world, comes near or at the bottom. The only tall building league London tops is the proportion of its skyscrapers designed by TAs: on the definition used in this paper - 25 percent compared to only 3 percent in Chicago and zero in Brussels or Benidorm. This, alone, is enough to demonstrate that the essential role of TAs in London is not that they have particular skills at designing tall buildings.

An increasing volume of literature demonstrates that British land markets are some of the most tightly regulated in the developed world (Cheshire and Sheppard, 2002, 2005; Cheshire and Hilber, 2008; Cheshire et al., 2015; Hilber and Vermeulen, 2016). Land supply for urban development has been tightly constrained since 1947 and supply for each legal category of use is separately regulated. There are also tight regulations on building heights throughout Britain. Every significant decision, moreover, is politically determined, so lobbies flourish and decisions are gameable.

\footnotetext{
1 Information on the number of skyscrapers or high rise buildings by city is from http://www.emporis.com/; data on population are from official figures and estimated for comparable metro areas, represented by Functional Urban Regions or Metropolitan Statistical Areas.
} 
"Trophy Architects" and design as rent-seeking:

Quantifying deadweight losses in a tightly regulated office market

Given such a system it was not surprising that Cheshire and Hilber (2008) found the regulatory burden on office development in London, measured as a Regulatory Tax (RT) as originally defined by Glaeser et al., 2005, was the highest estimated for any major office location in Western Europe. Only Brussels approached the low level of regulatory burden estimated for New York by Glaeser et al. (2005). According to Cheshire and Hilber (2008) across British cities this value of RT (measured as the difference between the price of office space and its marginal construction costs, as a percentage tax) far exceeded any found in European office centres. In London's West End it averaged 809 percent between 1999 and 2005. The highest value found in any year in Manhattan was 50 percent (Glaeser et al.; 2005). Cheshire and Hilber (2008) also provided direct evidence that regulatory restrictiveness was the primary cause of the high values of RT observed in Britain.

We have, therefore, good evidence that the system of land use regulation in Britain creates very significant economic rents. In an influential paper Krueger (1974)2 pointed out that if regulatory restrictions create economic rents, people and economic agents will compete for them and compete in a variety of ways ranging from outright illegality via, for example, bribery or extortion, to more benign and legal means. In so far as these rent-seeking activities do not take the form of productive activities or pure transfers they represent a deadweight welfare loss (see Krueger, 1974; or Posner, 1975). Even though the concept of rent-seeking and its implications have been influential, quantifying the magnitude of deadweight losses arising from even specific examples has proved to be difficult and comparatively few empirical studies exist (De Rosal, 2011). As Tullock (1997) complained: ‘...I have been perturbed by the difficulty of finding any actual measurable cost....' However, we argue that

2 Tullock (1967) had come up with a similar idea although it could be argued its origins go further back than even 1967. 
"Trophy Architects" and design as rent-seeking:

Quantifying deadweight losses in a tightly regulated office market

the use of trophy architects in London to gain permission to build bigger buildings on a given site is a specific case where we can produce a credible, if approximates, measure of the net deadweight losses arising from the employment of TAs as rent-seeking agents.

So far as we know Evans (1988), was the first to observe that Krueger's model translates almost precisely into the context of restrictive land use regulations and, in particular, applies to the British system of land use planning 4 . The specific mechanisms of the British system are particularly relevant to the issue of rent-seeking since, unlike the US Zoning or European Master Planning systems, the British system is not rule-based. Decisions in the British context, while informed by planning policies, are ultimately political; and therefore gameable5. The initial decision on whether to permit development is taken by a political committee - the Local Planning Authority (LPA).This can be appealed ultimately to the national government minister responsible for the planning system.

The quotation at the head of this paper is taken from such an appeal decision from the then minister deciding to give permission for the Shard - now the tallest building in London. The decision-making surrounding the Shard's route to gaining planning consent illustrates what we have in mind perfectly. Irvine Sellar, a real estate investor with no experience of large scale development, bought a building near London Bridge Station in 1998 purely as an investment (Sellar, 2015). Very soon afterwards the government announced it would encourage higher density development near transport hubs. Opportunistically Sellar thought

\footnotetext{
3 It is approximate for a number of reasons but one is that there could be unmeasured 'consumption benefits' from TA-designed buildings for tourists and passers-by. While we tested for 'external production' benefits from views or proximity to TA buildings and found none, there could still, however, be social benefits we fail to capture. 4 A similar point in the context of the US system was made by Sass and Pogodzinski (1990). Neither of these sets of authors attempted any quantification.

5 There are guidelines influencing decisions, such as the National Planning Policy Framework (DCLG, 2012) or local plans, but these are no more than guides, subject to political decisions within the legal framework.
} 
"Trophy Architects" and design as rent-seeking:

Quantifying deadweight losses in a tightly regulated office market

why not develop a 400 metres tall building with 8-times the internal space as the existing 1960s built HQ of PriceWaterhouseCoopers. He consulted the head planner at the Borough of Southwark (Fred Manson) and was told that 'it would need a signature architecture to win approval' (Guardian, 17 March 2017). Renzo Piano had won his second TA award, the Pritzker Prize, in 1998 so Sellar went directly to Berlin to recruit him for the project.

Although denounced by English Heritage, who inadvertently coined the name by which it is known claiming it would "tear through historic London like a shard of glass" the project ultimately gained permission. The government minister who was the final decision maker after the public enquiry, was John (now Lord) Prescott. He may not have been an architectural connoisseur but was persuaded of the building's 'highest architectural quality', surely helped by Renzo Piano’s recent award of the Nobel prize of architecture, and so gave permission. When asked if he would do a tall building in London again, given the immense difficulties, Sellar (2015) answered he would 'because it is very profitable'.

This is only anecdotal evidence of the causal link between employing a TA and obtaining permission to build taller. However, we have found persuasive and more systematic evidence from the comparison between London and Chicago reported in section IV. In London receiving one of the three awards we use to define TA status is associated with an architect's buildings becoming 11 floors taller: but in the unconstrained context of Chicago there is no height gain in their buildings at all. This does strongly support the conclusion that it is the reputational signalling power of an architect's lifetime achievement award, not the distinctive quality of a building's design, which allows a TA to game the system in London.

Despite the size of the economic rents potentially at stake, the British land use planning system produces few cases of proven corruption but it does appear to produce a rather more 
"Trophy Architects" and design as rent-seeking:

Quantifying deadweight losses in a tightly regulated office market

elevated form of rent-seeking activity on the part of developers: the employment of TAs to game the system and stack more floors onto a given site. We also find that the quantity of extra space obtained in this manner interacts with the local restrictiveness of the planning system. It is significantly more difficult to build taller in Boroughs with more restrictive planning regimes. While TA designed buildings do command a price premium per square metre, the additional value conferred on the site arises predominantly from the extra space in a TA building, so suggesting a substantial - in section V we estimate 62.5 percent of the increase - rent-seeking component. Buildings designed by TAs and located on sites where tall buildings are not absolutely prohibited, are systematically and very significantly taller - 14 floors taller - than those designed by 'standard’ architects.

Offsetting for the extra price per square metre of space we then compare the value of the extra space that TAs generate on a representative site with the direct costs of TA construction - their buildings cost more to build. We find that even with these higher construction costs TAs appear to represent a hugely profitable form of not just rent-seeking but rent-acquisition for the developer: a 152 percent increase in returns. The direct cost of more expensive construction appears to be only a small component of the additional costs associated with employing a TA to game the system, however. In particular, large TA schemes are subject to greater scrutiny and likely to be appealed at every stage with a greater probability of ultimate failure. This adds legal and consultancy costs and waiting time but, above all, increases uncertainty. This uncertainty will be translated into a greater risk premium and higher financing costs (Mayo and Sheppard, 2001). Developers will therefore require a higher expected rate of return to justify the gamble of hiring a TA to gain permission to build extra space on a given site. 
"Trophy Architects" and design as rent-seeking:

Quantifying deadweight losses in a tightly regulated office market

Given that the London real estate market is reasonably efficient and competitive (Cheshire and Hilber, 2008) we can infer that the rents we estimate for a representative site successfully developed using a TA are close to the expected costs of that rent-seeking6. Since we net out any 'productive value' of TA design by offsetting for the price premium their space commands, we can say that TA costs will also approximate the total deadweight welfare loss less, perhaps some external social benefits to people enjoying the view of the TA buildings. Note, however, that we tested for and found no evidence to support the possibility that views or proximity to TA designed buildings increase the value (so by implications benefits of) other office buildings.

Our paper proceeds as follows: we first explain the basic mechanisms of the British planning system focusing on its particular operation in London. The next section describes our data, followed by a section setting out our central empirical estimates of the impact of TA design on the size of office buildings. We then analyse the impact of TA design in terms of the price per $\mathrm{m}^{2}$ of built space and per $\mathrm{m}^{2}$ of site area. Section IV examines the evidence for our causal interpretation: that TAs are employed in London essentially as agents to obtain rents generated by restrictions on the supply of office space. In Section V, we compare the increase in the value of permitted space estimated for a representative site in the City of London associated with a TA to the extra construction costs employing a TA imposes. We then conclude.

\footnotetext{
6 In the rent-seeking literature this is termed the ‘complete dissipation’ hypothesis (see De Rosal, 2011).
} 
"Trophy Architects" and design as rent-seeking:

Quantifying deadweight losses in a tightly regulated office market

\section{THE PLANNING SYSTEM IN LONDON}

To understand how the rents we claim exist are generated and how prestigious design(ers) can be used to seek them, it is essential to understand some details of England's planning system and its particular features in London7. Permission to build is not given because of a quasi rule-based zoning system as in the US nor as in the even more rule-based Master Planning system of Continental Europe. Permissions rest on a process known as 'development control', exercised by the relevant Local Planning Authority (LPA) which is the smallest governmental jurisdiction. There are 357 such LPAs in England and 13 within inner London. Any building, qualifying extension or alteration, or any change of legal use requires development permission from the LPA. The LPA is composed of local politicians advised by professional planning officers. In October 201846 percent of English LPAs had an up to date local plan: the rest did not. Even when there is a local plan, decisions may not follow it; equally decisions may not follow the guidance of the professional officers. They are highly political and subject to lobbying. There is then a system of appeal, first to the planning inspectorate and then, beyond that, to the national government minister responsible for planning and development. In practice this means that the outcome of applications for development cannot be predicted beforehand, there can be long (5-years would not be uncommon) delays as decisions go through the three tiers of decision-making and all decisions are subject to lobbying and political pressure. This planning framework was established by the Town and Country Planning Act of 1947: so it has been in place in its essential form for 70 years.

\footnotetext{
7 Planning in the three countries of Great Britain shares many features but there are specific differences, particularly in Scotland. There are also some particular features of planning in London, especially in the City of London and Docklands - see text for details.
} 
"Trophy Architects" and design as rent-seeking:

Quantifying deadweight losses in a tightly regulated office market

While effectively established in 1947, there were earlier legal policies relevant for building in London going back to the $19^{\text {th }}$ century. Before about 1875 finance and technology restricted building heights but the invention of elevators and steel frames allowed for much taller buildings (Turvey, 1998). But height and building sizes in London became strictly controlled following the London Council Act of 1890 which set a statutory limit of $27 \mathrm{~m}$ plus two stories in the roof; then decreased in 1894 to $24 \mathrm{~m}$ plus $6 \mathrm{~m}$ to the rooftop (Inwood, 2005, p.211). Therefore neither skyscrapers - nor anything resembling skyscrapers - were built in London until after 1956, when these blanket height restrictions were finally abandoned. However even after 1956 the then London County Council continued to enforce plot-ratio restrictions of between 2 and 51/2:1, and individual London Boroughs separately maintained their own prohibitions on high rise building: some, such as Islington, continue even to 2019 to prohibit any building above 7 stories except for a small area bordering the City of London. The City itself gradually relaxed some restrictions during the 1980s and 1990s although specific provisions, such as Conservation Areas still prevent building high on a substantial proportion of its area (City of London, 2010).

In addition, there are sight corridors protected under the London View Management Framework along which no building may be higher than the base of the dome of St Pauls (see Figure 2), and additional height protected zones specified for areas surrounding the London Monument, the Tower of London, the Thames River, and a number of historic and skyline features (City of London, 2012). These height restrictions cover a large proportion of inner London - 75 percent of the Borough of Westminster, for example, has Conservation Area status. Individual buildings may also be 'Listed': given historic preservation status that forbids any external or internal alteration. There are more than 30,000 such buildings in Inner London. 
To summarize, therefore, the planning and related policies that are strictly relevant for the analysis in this paper are:

1. Decisions on development applications are made by means of 'development control' - so decisions to permit any legally defined development are typically discretionary, made by locally elected politicians and subject to appeal. This process is quasi-judicial in character but ultimate power of decision rests with the responsible national minister when the appeal process is exhausted8;

2. Absolute height restrictions prior to 1956;

3. Plot-ratios (equivalent to Floor Area Ratios) restricting the allowable floor area on a given site thereafter until the 1980s and 1990s;

4. Continuing binding height restrictions within; Conservations Areas, Protected view lines of St Pauls extending as far as $16 \mathrm{kms}$, the Houses of Parliament, the Monument, the Tower of London, the Thames Policy area, and an absolute ban on the re-development of the numerous Listed buildings in Central London.

\section{DATA}

Descriptive statistics are shown in Tables 1 and 2.

\section{II.i Sample of buildings and sales}

Data on office building characteristics and sale prices were obtained from Estates Gazette (EG), CoStar and Real Capital Analytics (RCA). Our aim was to capture the whole

\footnotetext{
8 Development has a legal definition under the 1947 Act and subsequent amendments to that Act. In effect it relates to any change of use of an existing plot of land or building unless the change is exempt. Very small extensions or alterations outside Conservation Areas are exempt but all office construction or change of use from, say, a shop to an office, even without physical alteration, would constitute 'development' and need permission.
} 
population of office buildings sold in Inner London9 between 1998 and 2018. Combined, there were some 6,500 unique sales over this period. This dataset however had to be cleaned and supplemented with additional information about individual buildings and we restricted the sample to purpose-built office buildings of three or more floors and at least $150 \mathrm{~m}^{2}$ of floorspace to avoid offices in shops or industrial premises or other buildings designed for other purposes. We also discarded all sales which occurred less than 12 months following the previous sale (Clapp and Giacotto, 1999). The location of buildings in the sample is shown in Figure 1. The resulting final number of distinct buildings was 2,039 which, allowing for those sold more than once, yielded a total of 2,739 sales.

\section{Tables 1 \& 2 here: Descriptive statistics for building size and hedonic regressions}

\section{II.ii Trophy Architects}

Architectural excellence is necessarily a subjective judgment but peer recognition seems the most objective measure available; it also - for purposes of testing our hypothesis - has the advantage of visibility to politicians and planners. We have taken the lifetime achievement awards from the Royal Institute of British Architects (RIBA), the American Institute of Architects (AIA), and the Pritzker Prize as the most prestigious and obvious recognition of architectural excellence and so classified all winners as 'TAs'. We adopt this term to emphasize that we are identifying not necessarily the 'best' architects but those with the most powerful signalling power of architectural merit.

For regressions on building size, buildings are recognized as designed by 'TAs' if the architect's first TA award had been conferred before the building in question received planning permission. For the regressions involving building sales, a sale is defined as a 'TA

9 For the relevant definition of Inner London see Dericks (2013). 
sale' if the architect had received their first TA award before the building sale. Additionally, in the case of eponymous architectural firms, the architect who won the relevant TA award must have been alive and working at the time the building was designed. By these definitions our data yielded 105 TA buildings in the size sample and 186 TA building sales. The architects and the tall buildings in our sample are discussed in Appendix 3. Of the 105 buildings designed by TAs in the size sample, 41 were built before 1956 (between 1870 and 1928), and therefore in an era when available technology or statutory regulations absolutely restricted their height. These pre-1956 buildings are referred to as 'Pre-Modern’ TA buildings in contrast to 'Modern' TA buildings. Of the remaining 64 modern TA buildings, 27 are located outside a Height Protected Area (HPA) and so had potential flexibility with respect to their size via the process of development control and TA signalling power. This means the number of observations available for identification is relatively small but cannot be increased since it constitutes the entire available population of such buildings.

\section{II.iii Planning and amenity data}

Data on Conservation Areas was acquired from English Heritage as was data on the 'Listed' status of buildings. Analysis revealed that roughly half of the total land area sampled is covered by Conservation Areas. Of the 2,039 buildings in the sample, 29 percent were built while within a HPA and 19 percent are now Listed.

\section{Figure 1 here: The 546 postcode sectors and 2,039 office locations}

The variables Conservation Area density, Listed Building density, and Parks \& Gardens density were estimated by; (i) calculating the area contained within each separate boundary, (ii) randomly placing a point for each $100 \mathrm{~m}^{2}$ of Conservation Area or $10 \mathrm{~m}^{2}$ in the case of the other two, within the area delimited by that boundary, and (iii) then summing the number of 
"Trophy Architects" and design as rent-seeking:

Quantifying deadweight losses in a tightly regulated office market

points for each variable falling within a 300m radius of each office property. The $300 \mathrm{~m}$ radius was chosen for these variables as in each case it performed better in our hedonic models than $100 \mathrm{~m}$ or $500 \mathrm{~m}$.

For the analyses of the effects of HPA status, buildings are recognized as such if they were built within any of the following areas after the relevant height restriction came into force: Conservation Areas, St Pauls Heights Policy Area, Monument Viewing Corridors, Tower of London Local Setting, London Strategic Viewing Corridors, Thames Policy Area, or areas deemed sensitive due to proximity to historic or landmark structures. A building is not regarded as being built in a HPA if the site was occupied by a 'tall' building before the area became height protected, and therefore ‘tall’ building permission was effectively grandfathered (where 'tall' is defined as exceeding the normal permissible height on the site at the time redevelopment was approved). Figure 2 maps these areas. For the price models, buildings were defined as located in a HPA if the building was located within a HPA at the time of sale.

\section{Figure 2 here: HPAs}

\section{II.iv Planning permission refusal rate}

To measure the restrictiveness of LPAs we use the data set on office planning refusal rates from 1990 to 2008 collected by Hilber and Vermeulen (2016). Since we use refusal rates purely as a control, any reverse causation does not affect our analyses (Ioannidis and Silver, 1999). As the City of London and the Docklands LPAs have exceptional planning regimes, measured 'planning restrictiveness' in these areas may imply something rather different. To reflect this we add specific dummies for them in the building size models. 


\section{II.v Employment density}

Data on annual 2000-2008 postcode sector local employment in London is taken from the NOMIS Annual Business Inquiry (ABI) Employee Analysis. Following Wheaton et al. (1997) who found that the primary driver of office demand in London was financial and business services employment, we only include employees in our measure in 2003 SIC codes $\mathrm{J}$ or K; corresponding to banking, finance, business services and insurance.

The number of points corresponding to the employment counts within the boundaries of each of the 546 postcode sectors (excluding areas in which there could be no employment such as parks and water bodies) were randomly placed within each boundary for each year. Systematic testing in the hedonic model showed that coefficient size and statistical significance peaked at $600 \mathrm{~m}$ and declined monotonically in both directions from there. Previous empirical studies of the effect of employment density on economic outcomes such as Arzaghi and Henderson (2008) or Jennen and Brounen (2009) found that employment within 500m of office buildings corresponded to the optimal radial bandwidth for New York and Amsterdam. We found results of the hedonic models were not changed according to whether estimates for employment in the building itself was included or not in our calculations. For our building size analyses, because our employment measure was only available from 2000 while many of the buildings were built before the 20th century, the mean 600m employment between 2000 and 2008 is used as a proxy for the employment levels relevant for the building at the time of construction.

\section{II.vi Access to labour force}

Access to the labour force was represented by distance to the nearest underground (subway) or other rail station. 


\section{II.vii Building characteristics and submarkets}

Submarket dummies were based on the EG's definition and details are shown in Appendix 1. The building quality measure comes directly from EG, which grades each floor of a building as either A or B. Buildings with only grade A space are graded as an A, both A and B space graded as A/B, and B space only is the omitted dummy variable. Additionally, a dummy for the decade in which the building was constructed is included.

\section{ANALYSIS}

\section{III.i Can TAs build bigger?}

The first question is whether office buildings designed by TAs have more floorspace on a given site. Before 1956 the height of a building was fixed by either statutory regulations or technology so we do not expect to find any TA effect for buildings built before then. We also do not expect to find that even the most acclaimed architects would have been able to flex the regulations governing the height and appearance of buildings built in a designated HPA10. We test this hypothesis for total floorspace relative to site size and then for height alone.

\section{Table 3 here: Can TAs build bigger? Dep. Var.: Total floorspace/ site area}

Table 3 reports the results where total floorspace relative to site area is the dependent variable. Model 1 simply lumps all TA buildings together and has few controls. Since we only expect TAs might plausibly be able to build bigger outside a HPA and after 1956, Model 2 interacts a Modern TA dummy for the building with built outside a HPA. The resulting co-

\footnotetext{
10 Though we do find one exception - the 16-floor New Court new Rothschild HQ building by TA Rem Koolhas was negotiated with City planners in a Conservation Area. It was the fourth rebuild or extension to the Rothschild's HQ since 1800.
} 
efficient suggests a much bigger effect and just being a TA no longer has a significant impact. Subsequent models add the decade in which the building was constructed, dummies for the City of London and Docklands, and then in Model 5, the local density of employment around the building. The basic result that Modern-TA buildings are significantly bigger is supported, and we see that the ability of a TA to get more space is confined to sites outside HPAs: and that all buildings are significantly smaller relative to the size of their sites, the more restrictive the local planning regime is. Consistent with a role for local agglomeration economies we also find that, all else equal, buildings are bigger the greater the local concentration of office employment is around them.

Given the relatively small number of TA buildings outside a HPA there has to be concern as to the robustness of these findings. The results reported in Table A1 provide some checks. We apply the quite stringent test of successively dropping the TA building outside a HPA with the largest floor to site area ratio, then the two largest and finally the three largest. Very reassuringly almost nothing changes except, obviously, the estimated extent of the additional floorspace a TA generates for a given site outside a HPA.

\section{Table 4 here: Can TAs build taller? Dep. Var.: No. of floors above ground level}

The way TAs succeed in getting more office space on a given site is revealed in Table 4. Their buildings are very much taller. Outside a HPA their buildings have more than 14 extra floors compared with a median building height across the sample of just 7 floors and so are almost 60m taller than buildings designed by standard architects (SAs).

Not surprisingly, within HPAs all office buildings tend to be lower and the effect of the other variables of interest, local employment density and planning restrictiveness continue as in 
Table 3. As before we subject the results to the robustness test of successively dropping the three tallest buildings. Again results are not affected (see Table A2).

That TA buildings are taller does not exclude the possibility that they also have a larger footprint on a given site. Table 5 shows the results of testing this idea. It reveals a more complex situation. Inside a HPA all buildings have a larger building footprint to site area ratio presumably as developers strive to get additional floorspace on a given site without adding to height. Modern TA status outside a HPA, however, has little significant effect although the effect is positive and significant at the 10 percent level in the most completely specified model, model (4). The general effect of TA design, however, is significantly to reduce the footprint to site area. The effect of other variables on the size of the building footprint relative to that of the site remain much as previous results would lead one to expect. More restrictive LPAs are associated with significantly smaller building footprints, other things controlled for, but greater concentration of local office employment increases the size of a building's footprint.

Table 5 here: Can TAs get a bigger building footprint? Dep. Var.: Footprint/ site area

\section{III.ii What is the value associated with a TA?}

We see that TA buildings are bigger so they have more rentable space which, all else equal, will increase their value but other factors associated with TA design may raise or reduce capital values per $\mathrm{m}^{2}$. While a TA building could command a rent premium, a less conventional layout might reduce the rent per $\mathrm{m}^{2}$ or the proportion of space that is usable. Unconventional building materials or design might also impose additional maintenance costs (for example, the costs of cleaning angled windows in Norman Foster's 40-floor Gherkin 
building). The unusual design might mean (and we find some evidence of this - see online Appendix 4) it takes longer to rent out a building: this would reduce the price but not the observed rents. Accordingly, rents and capital values could be affected differently: rent per $\mathrm{m}^{2}$ might rise because of prestige but less rentable space or higher maintenance costs might nevertheless reduce capital values overall. In sum, we cannot predict the net effect of TA design on value per $\mathrm{m}^{2}$ a priori: it is an empirical question.

We investigate by means of a 'classic' hedonic model. The focus of our interest is on several characteristics of buildings and their settings and also on specific price estimates. Recognizing the well-known problems of omitted variables we have made great efforts to incorporate as wide a range of relevant control variables as possible and, in particular, the impact of TA design on price. We have also looked carefully to see if there is evidence supporting the emerging tall buildings literature (see for example Liu et al., 2018): an ultimately rising value for taller buildings all else equal.

\section{Table 6 here: What do TAs yield in price/m² of building? Dep. var.: $\ln ($ price/m²)}

Results are reported in Tables 6 and 7. Note that whereas previously we have been analysing the physical characteristics of 2,039 buildings, we are now measuring the capital value per $\mathrm{m}^{2}$ achieved in 2,739 transactions over the period 1998-2018 from those same buildings. White tests do not reject homoskedasticity, and so normal standard errors are reported.

The dependent variable in the models reported in Table 6 is the observed price with the building's floor area included as an independent variable. The results for all models confirm that a building's price is increased if it is in a HPA or local planning is more restrictive (both making space relative more scarce). They also provide evidence supporting the importance of 
"Trophy Architects" and design as rent-seeking:

Quantifying deadweight losses in a tightly regulated office market

localised agglomeration economics: the effect of localised employment density in the primary office sectors on a building's price is always highly significant and positive. Some wholly insignificant variables are not shown: for example in no models experimented with did the number of parking spaces have any significant effect on a building's price. This is perhaps not surprising for London given the reliance on public mass transit and the congestion charge on cars using the central zone where almost all the buildings in the sample are located. The effect of most other variables is as might be expected.

Two aspects of buildings have been explored more intensively. The first relates to design; the second to its own height. It has been suggested that 'Listing' a commercial building might reduce its value (Cullingworth and Nadin, 2015, p.242) since its fabric cannot be adapted or modernized; but historic designation might also be associated with a higher value. Our results show that not only do Listed office buildings in London command a premium but having more Listed buildings in the vicinity of the building sold also significantly increases its price. We also find a significant premium for TA design although the significance of the premium seems to be eroded somewhat once the building height is controlled for (models (2) and (4)). We also explored the possibility that views of, or proximity to, TA-buildings increased a given building’s price, so suggesting possible production externalities. We experimented adding (i) TA building counts over distance bands of 600m, 800m, and 1000m, while (ii) varying our TA sample to only reflect buildings above 7 floors, the minimum height necessary to have any real views, (iii) summing up all the floors above 7F of nearby TA buildings, (iv) summing up the number of TA awards earned by TAs of their nearby buildings, and interactions between either (ii) or (iii) with (iv). None of these specifications yielded a significant price effect (result available from authors). 
"Trophy Architects" and design as rent-seeking:

Quantifying deadweight losses in a tightly regulated office market

There is, in London, as in the Netherlands, a documented rental premium for higher floors see Cheshire and Hilber (2008) and Koster et al. (2014b). Moreover there is an emerging literature on tall buildings and vertical agglomeration economies. Our data is not ideal for fully exploring this aspect of building price since we do not have price or rent by floor: only the total price of individual buildings of known height. We tried to reflect the evidence of Liu et al., (2018) who found that the ground floor commanded a substantial rent premium but the rent for the first floor (in UK usage - second floor in US usage) fell by 50 percent with rising rents thereafter and a more rapid acceleration above some 30 floors. We are not able to estimate the marginal effect on price of more floors but models (3) and (4) include dummies for the impact of a building being more than 11 and less than 20 floors; between 21 and 30 floors; or taller than 31 floors. The number of observations of buildings more than about 20 floors makes it difficult to have finer classifications. We see all three classes increase a building's price all else equal with the biggest and most significant increase for the tallest buildings. The intermediate class - 21-30 floors - though positive is imprecisely estimated and not significantly different from the 11 to 20 class.

TA design in all models does appear to have a significant impact on a building’s price suggesting some productivity advantage accruing to its occupiers. We have already seen that TA design achieves larger - notably taller - buildings on a given site if that site is not in a HPA. So now let us turn to estimating the impact that TAs have on the total price of a building on a given site allowing for both these impacts: buildings which are both bigger and more valuable per $\mathrm{m}^{2}$. The results are reported in Table 7 where the dependent variable is the price paid for the building per unit area of its site. 


\section{Table 7 here: What value does a TA add to a site? Dep. var,: $\ln \left(\right.$ price/site area $\mathbf{m}^{2}$ )}

The models follow closely those reported in Table 6 but include whether the building was inside a HPA when planning permission was granted and also interacts this with whether it was designed by a TA. We see that in all specifications the interactive benefit of a TA building built outside a HPA (and so with those extra floors on a given site) is substantial and significant. The total effect on a building's price relative to the size of its site, if it is designed by a TA outside a HPA, is the value of the TA and 'TA outside HPA' coefficients summed. In the most preferred specification - reported as Model 4 - the combined effect of these two factors is approximately .923, or, given the semi-log specification, a 152 percent increase in average building price 11 .

Taken together, TAs both have a significant influence on the price per unit of floorspace, and produce significant value outside HPAs through increasing total floorspace by building some 14 floors taller.

\section{CAUSATION}

For these results to allow us to infer anything about the costs of rent seeking there has to be a causal relationship. Employing a TA must be a mechanism developers use to signal that their building is of 'exceptional architectural merit' and so influence decision-makers to relax height restrictions to capture the economic rents London’s planning restrictions generate. However because of the nature of our data, no obvious instruments are available nor are other standard econometric tools employed to establish causation feasible. We address this critical issue of causation, therefore, by assembling a combination of mutually re-enforcing evidence

11 See Kennedy (1981) for this calculation. 
for TAs’ causal effect on building height in London. We first conduct a quasi-natural experiment on what happens to the height of buildings when an architect gains TA status in:

a) the highly regulated, space-constrained but gameable context of London where rentseeking should be expected to have a reward, compared to; b) the unconstrained and difficult to game context of Chicago where there are no rents to be gained. While our sample of buildings in the two cities is exhaustive, indeed is the whole relevant population so far as we are able to discover, the combined sample is still only 86 or 87 buildings so may not be judged wholly persuasive. It should be noted that this is not a simple extension of the sample of TA-buildings. Indeed, since in our definition to be classified as a TA-building, a building had to have received planning permission before the architect's first TA award was conferred, many are not TA buildings. They were designed before their architect had become a TA.

We then systematically rule out plausible alternative explanations as to why offices designed by TAs on non-Height Protected sites in London could be so much taller than those designed by SAs and also demonstrate that being a TA is not in general associated with the ability to design tall buildings. In our judgment, taken together this evidence generates a kind of triangulation process: while none on its own may be conclusive, in combination the evidence is very persuasive.

\section{IV.i Quasi-natural experiment}

Our specific definition of a 'Trophy Architect' necessarily implies that buildings which were designed by a TA before they won a relevant award are not classed as 'TA buildings' Therefore in practice different buildings by the same designer have different 'TA' statuses. We exploit this fact to test for causation by examining what happens to building height when an architect gains TA status in two very different regulatory contexts. 
As previously noted, the supply of office space in London is tightly restricted by the planning system but decisions within that system are eminently gameable because they are discretionary. In contrast, in Chicago, it is reasonable to assume potential 'rents' from getting more office space on a given site are negligible because, as in New York (see Glaeser et al., 2005, p354) regulation has a negligible restricting effect on the supply of office space. This has been recently documented in a number of studies (Barr, 2013; Ahlfeldt and McMillen, 2018). All height restrictions were removed in Chicago in 1923 although Floor Area Ratio restrictions, though generous, remain. Moreover, the system of land use regulation there, as elsewhere in the US, is 'rule-based' and so is much more difficult to game than the British system.

If employing a TA is a rent-seeking mechanism in London, then the receipt of TA status should be associated with the architects' buildings becoming considerably taller. Their newly acquired status means they can now be employed to signal the architectural merit of their buildings (that 25 percent of all London skyscrapers are TA designed compared to 3 percent in Chicago is already highly suggestive). By contrast in Chicago we would not expect buildings to increase in height once their designer gains TA status. We test this hypothesis and report the results in Table 8.

There are necessarily a restricted number of observations but we made a great effort to include all buildings from architects active in either London or Chicago since 1923 and who designed both before and after their TA award. The individual Chicago buildings are itemized and described in Table A7. 
"Trophy Architects" and design as rent-seeking:

Quantifying deadweight losses in a tightly regulated office market

What we want to estimate is the increase in height observed in, respectively, London and Chicago following the award of TA status. Given our sample size restrictions we limit independent variables to; London/Chicago, TA/non-TA status, and Built in/Outside HPA dummies combined with their two and three-way interactions, and five decade built dummy controls. Given that some such interactions are empty sets the model we fit, therefore, is:

$$
\begin{aligned}
& \text { Floors }=b_{0}+b_{1}(\text { London } \times T A \times \text { Built Outside HPA })+b_{2}(\text { Chicago } \times T A)+ \\
& b_{5}(\text { Chicago })+b_{3}(T A)+b_{4}(\text { Built in HPA })+b_{6}(\text { decade built dummy })+\epsilon
\end{aligned}
$$

where,

$$
b_{0}=\text { constant }
$$

$b_{1}=$ the causal effect of TAs on building height outside HPAs in London

London/Chicago = building is located in London or Chicago

$T A=$ building designed after architect received their TA status

Built in/Outside HPA = building built in a HPA at time of construction. None of the Chicago buildings are assumed to be in an HPA - so applies only to London buildings

The results reported in Table 8 show that, all else equal, buildings in Chicago are a lot taller than in London (depending on the specification some 27 to 35 floors taller). But in Chicago gaining TA status adds nothing to a building's height - indeed if anything once an architect has gained TA status their buildings tend to be shorter; but this height reduction is not statistically significant. In London, in contrast, consistent with our underlying hypothesis, gaining TA status leads to a substantial and highly significant increase in building height. In the models with age controls the gain is between 9 and 11 floors (Columns 2 and 4). In our judgment the results reported in Column 4, with age controls but omitting 1 Canada Sq. are 
"Trophy Architects" and design as rent-seeking:

Quantifying deadweight losses in a tightly regulated office market

likely to be the most reliable. This is because this building was constructed when the area was controlled by the London Docklands Corporation which operated special planning rules designed to maximize development, thus making it unnecessary to try to 'game the system' to get extra space on a given site. These results imply that the effect in London of gaining TA status is estimated to add a similar - certainly not statistically different - height to a building as the average effect estimated for our full sample of TA buildings (10.82 floors vs 14.29, see Table 4). Given the size of their standard errors it is not possible to be absolutely certain that the Chicago and London effects of the award of TA status are significantly different: but it is highly probable that they are12.

So while the sample is necessarily small in both cities, the results support our hypotheses quite strongly. The evidence from this quasi-natural experiment - what happens to building heights when an architect achieves TA status - provides highly suggestive support of our interpretation: that in the specific conditions of London TA status has powerful signalling power of architectural merit and is used to gain the rents created by a highly restrictive but gameable planning system.

\section{IV.ii Plausible alternatives}

Following extensive consultation with colleagues and industry experts, we identified two alternative plausible reasons why TAs might be favoured for designing tall buildings. The first is that firms wanting to build prestigious headquarters and make a statement may both build tall and employ a TA to do so. Another possibility is that the technical skills required to design and build tall buildings are rare and highly skewed in their distribution to TAs. These

\footnotetext{
12 An even simpler test is just to estimate for each city's set of buildings the change in floors associated with the architect gaining TA status. In London this is an additional 11.92 floor with a standard error of 2.975: in Chicago, 5.256 fewer floors with a standard error of 6.999.
} 
"Trophy Architects" and design as rent-seeking:

Quantifying deadweight losses in a tightly regulated office market

two alternative causal explanations are explored in detail in Appendix 3, where we first compare the bespoke status (that is buildings commissioned by a firm for its own occupation) of all the 'tall' - over 20 story - modern TA buildings in London. We find no evidence that either tall or TA buildings are systematically more likely to be bespoke. It appears, therefore, not to be the case that the exceptionally high frequency of TA design for tall buildings in London is because tall buildings are commissioned by the companies occupying them to 'make a statement'.

To explore the second possible explanation - that only TAs have the capability to build tall Table A6 compares the tallest buildings in five international cities, selected because they are known to have less restrictive land use regulatory systems than London. Across these five cities only 2.3 per cent of tall buildings were designed by TAs compared to 25 percent in London. Moreover in the two least regulated cities, Brussels (which had the lowest estimated level of regulatory tax of any European office centre in Cheshire and Hilber, 2008) and Benidorm, not a single tall building was designed by a TA. Clearly the expertise necessary to design tall buildings is not restricted to architects who qualify as TAs by our definition. This second alternative explanation is also hard to reconcile with our specific definition of a 'Trophy Architect', which necessarily implies that buildings which were designed by a TA before they won a relevant award are not classed as 'TA buildings'. Therefore in practice different buildings by the same designer may have different 'TA' statuses.

\section{WHAT IS THE NET VALUE OF RENTS OBTAINABLE BY DESIGN?}

We have demonstrated that TAs may be able to generate more value both by building taller on a given site and because of the TA-premium per $\mathrm{m}^{2}$ their buildings command but they also cost more. Some of these extra costs can be estimated directly but most, as we argue below, are likely to be hidden because they represent delays in securing permission and extra risks 
"Trophy Architects" and design as rent-seeking:

Quantifying deadweight losses in a tightly regulated office market

for a project including, of course, the risk that no permission will be forthcoming. We first look at those costs we can directly estimate.

From Table 4 we can assume that TA-buildings outside a HPA will be some 14 floors taller than SA buildings. This would mean that employing a TA would allow a developer to go from a typical allowable building height of 7 floors to 21 . Our task here is to estimate how valuable this increase in floorspace is to a developer allowing for the extra costs, explicitly associated with TA building and design. To address this we apply cost and net floorspace data obtained from Gardiner \& Theobald (G\&T) for a hypothetical building in the City of London with characteristics approximating the sample median for this location: 8 floors (not 7 as for the sample as a whole), a $2000 \mathrm{~m}^{2}$ site area and $1600 \mathrm{~m}^{2}$ footprint. We then compare these cost and net floorspace estimates with those derived from the methodology of Ahlfeldt and McMillen (2018), henceforth referred to as 'A\&M'.

TAs charge a premium for their services compared to SAs, and the buildings they design on average incur additional construction costs both because they are taller and because their unit costs per $\mathrm{m}^{2}$ are higher. G\&T provided estimates of the total construction costs for a standard office building and more expensive TA designs, as well as estimates for the loss of net internal area as office buildings increase in height.

Using the sample median characteristics of office buildings in the City of London, the coefficients in Table 6, Model 4, and the estimated selling price (including the TA-premium) of a TA building, we calculated a sale-price $/ \mathrm{m}^{2}$ time-series for these hypothetical buildings at 8 and 22 floors across the study period. The results are displayed in Figure 3 along with estimates for the cost $/ \mathrm{m}^{2}$ of expensive TA and SA buildings by number of floors. 
Figure 3 about here: Price per $\mathbf{m}^{2}$ and construction costs for representative TA building in City

As we can see, estimated price per $\mathrm{m}^{2}$ was highly cyclical but always well above TA building costs, suggesting that a considerable rent could have been earned by using a TA at any time between 1997 and 2018. These achievable TA rents also appear to have trended higher over time.

Given this data we can estimate both the value of surpluses (not profits since this will include the price bid for land, rent-seeking costs, etc.) and the components of those surpluses generated by an SA or a TA for 8- and 22-floor buildings. In the case of a TA the components are the result of additional surpluses accruing from (i) the increase in space and (ii) from the TA-premium accounting for the additional direct costs TA design entails.

\section{Table 9 about here: SA and TA height and surpluses according to Gardiner \& Theobald (G\&T) and Ahlfeldt \& McMillen (A\&M)}

As shown in Table 9, assuming the market price for office space is $£ 14,000 / \mathrm{m}^{2}$, and following G\&T’s costs and net floorspace protocols, an 8-floor SA building will generate a $£ 110 \mathrm{~m}$ surplus while a TA design of 22-floors will generate a total surplus of £326m. The difference between the 8-floor SA and 22-floor TA implies a gain of $£ 216 \mathrm{~m}$ from using a TA. The additional surplus accruing to the 22-floor TA building of $£ 216 \mathrm{~m}$ can be further broken down into a TA price premium (£81m) representing a productivity gain, and the value contributed by the increase in 14 additional floors as the residual (£135m) - a rent. 
"Trophy Architects" and design as rent-seeking:

Quantifying deadweight losses in a tightly regulated office market

By contrast, the total economic rent theoretically available to an SA if they were able to build to the profit maximising height of 117 -floors instead of 8 is $£ 783 \mathrm{~m}-£ 110 \mathrm{~m}=£ 673 \mathrm{~m}$. This suggests that for a new office building in the City of London, by restricting heights to 8floors as opposed to the profit maximizing 117 there is foregone rent of $£ 673 \mathrm{~m}$. TAs in the right location, however, are able to claw-back some $£ 135 \mathrm{~m}$ of this through height concessions from planners. These, however, are strictly partial equilibrium calculations: if height restrictions were removed for the market as a whole, the consequent increase in the market-wide supply of space, and fall in its price, would significantly reduce the profit maximizing building height - and of course eliminate TA rents and deadweight losses.

Using the G\&T cost estimates the additional cost of the 22-floor TA building relative to a 22floor SA building is $£ 14 \mathrm{~m}$ : on A\&M cost estimates only $£ 6 m$. In practice some fraction of this $£ 14 m$, say 'p’, will comprise opportunity costs and therefore represent a deadweight loss, and the remaining fraction will represent a pure transfer to TAs and perhaps construction firms. The magnitude of 'p' will depend upon the particular works these firms undertake relative to a standard 22-floor building and the competitiveness of the TA and construction markets.

Given the apparent substantial rents (£135m) to be earned from hiring a TA to build tall, the natural question to ask is why do not all developers with land outside HPAs seek (and acquire) rents this way? In the context which we are analysing, the most plausible answer is that since there are no $£ 50$ notes lying around on the pavement, let alone $£ 135$ million pound notes, there is ‘complete rent dissipation'. As was argued in Cheshire and Hilber (2008) there is good evidence that the development industry in London is competitive - a similar conclusion to that reached by Glaeser et al. (2005) in their analysis of the extent of the 
"Trophy Architects" and design as rent-seeking:

Quantifying deadweight losses in a tightly regulated office market

regulatory tax in Manhattan. This suggest that in equilibrium expected actual profits are the same regardless of whether a TA or a SA is employed. All rents are dissipated in rent-seeking activity of one sort or another.

The estimates of rents made so far, however, assume no extra costs beyond those associated with actual design and construction. There are, however, likely to be at least three additional and important sources of cost. The first is extra costs negotiating a way through the process of development control ultimately to obtain permission to build, including the professional fees and expenses involved plus the financing and opportunity costs of the extra delay this imposes. The second is the possibility that TA designed buildings have certain financial penalties associated with them. The third is more intangible. It is the higher expected rate of return that would be required by the developer to offset the greater risks that trying - and perhaps failing - to game the system.

We provide some admittedly fragmentary evidence in Appendix 4 that supports the view that applications for tall buildings designed by TAs take 6-18 months longer to process, and that space in large buildings takes 28-60 months longer to fully let. Although we are not able to estimate the costs of additional planning delay, we do find that the cost imposed by longer letting-times would reduce the profit of our representative TA building by $£ 9 m$. Note that all three such costs should be regarded as deadweight losses. Assuming these costs completely dissipate rents and adding the $£ 6$ to $£ 14 \mathrm{~m}$ extra cost associated with using a TA yields an upper limit for the gross surplus or available rent of $£ 216 \mathrm{~m}-£ 230 \mathrm{~m}$. If we then net out the productive $£ 81 \mathrm{~m}$ TA floorspace premium, we arrive at an estimate of the net deadweight loss of $£ 135 m-£ 149 m$. 
"Trophy Architects" and design as rent-seeking:

Quantifying deadweight losses in a tightly regulated office market

However, from a social welfare perspective these estimates ignore any external benefits that could be associated with TA design. We have already investigated but found no evidence of productive externalities (views of, or proximity to, TA buildings increasing the price of other buildings) but there could be social value to residents or tourists from viewing such buildings. There is evidence that both historic and modern architecture create some external benefit for residents (Koster and Rouwendal, 2017; Ahlfeldt and Maennig, 2010; Ahlfeldt and Mastro, 2012). So this potential source of external benefit has to be weighed against our estimate of the gross value of deadweight losses. . While the evidence for such external benefits associated with TA designed commercial buildings is sparse, nevertheless we should note that in so far as they exist, they imply that our $£ 135$ to $£ 149 m$ would clearly be an upper bound estimate for the net deadweight losses arising from TA rent seeking behaviour.

\section{CONCLUSION}

We have come a long way to answering one of the questions posed at the start: why does the incidence of tall buildings vary so much across cities? London has very few because of very tight regulation combined with high costs in negotiating exceptions by using a TA. While it is a partial equilibrium result, the profit maximizing height for a new office building in the City of London, if such a building could be built employing a SA, would be 117 -floors. We observe that 'normal' new office buildings average 8-floors. That such a tall building would be profit maximizing reflects the tight restrictions on London’s supply of office space investigated in Cheshire and Hilber (2008).

This paper provides evidence consistent with Krueger’s 1974 analysis. If you have a system of regulation which imposes quantitative restrictions on the supply of some 'good' it will 
"Trophy Architects" and design as rent-seeking:

Quantifying deadweight losses in a tightly regulated office market

create rents, which actors will then compete for. In the quasi-discretionary planning system operating in London we find that developers seem to be able to appropriate those rents literally by design(er). They can employ TAs who, where the regime is at all flexible - that is in the areas not absolutely but discretionally regulated for height - can use their prestige to signal superior aesthetic quality and persuade planners and politicians to permit more building space on a given site, notably by allowing a taller building. Moreover, we have found quite persuasive evidence from the comparison with Chicago suggesting that it is not the intrinsic quality of the design so much as the signalling power of a major lifetime achievement award which is responsible for this effect. In London, unlike the far less restrictively regulated Chicago, the receipt of TA status is associated with the architects' subsequent buildings 'growing' by some 11 floors in the specification we judge most persuasive.

Even allowing for the additional direct costs entailed in building to a TA design, the extra space a TA can generate on a given site increases the profits of their typical buildings. On a representative site this is worth an estimated $£ 216 \mathrm{~m}$ of which $£ 135$ appears to represent rents while $£ 81 \mathrm{~m}$ represents the additional premium TA designed space commands. The results from Table 7 provide an alternative way of estimating a TA's addition to site value: an increase of 152 percent. However, while $£ 135$ m may be a best estimate of the value of the rents that employing a TA appears to generate, if we turn the telescope around the other way and assume that large denomination bank notes are not lying around on the pavements of London to be picked up, this $£ 135 m$ can be interpreted as simply a measure of the costs imposed by the planning system if it is to be gamed successfully: the cost of rent acquisition using a TA. Thus $£ 135 \mathrm{~m}$ combined with up to $£ 14 \mathrm{~m}$ in extra construction costs represents the upper bound estimate for the gross deadweight losses associated with TA design of a single 
building. However, it omits any external social value which a TA building might also generate and only a fraction of the $£ 14 \mathrm{~m}$ extra costs may represent a true deadweight costs.

Certainly seeking and acquiring rents by employing a TA has costs, most of which (such as employing lawyers and planning specialists to pursue appeals against initial rejections or additional risk premiums) are deadweight losses; and if there is a case for more high quality architecture than the market will deliver, London almost certainly uses a suboptimal method of generating that increase. The current planning regime also delivers any residual rents more or less randomly to lucky developers and lucky TAs who succeed in flexing the regulations.

\section{References}

Adeney, M. (2017) 'Irvine Sellar Obituary’, The Guardian March 7, https://www.theguardian.com/artanddesign/2017/mar/07/irvine-sellar-obituary

Ahlfeldt, G. and Maennig, W. (2010). ‘Substitutability and Complementarity of Urban Amenities: External Effects of Built Heritage in Berlin', Real Estate Economics, 38(2): 285-323.

Ahlfeldt, G. and Mastro, A. (2012). 'Valuing Iconic Design: Frank Lloyd Wright Architecture in Oak Park, Illinois’, Housing Studies, 27(8): 1079-1099.

Ahlfeldt, G. and McMillen, D. (2018) 'Tall Buildings and Land Values: Height and Construction Cost Elasticities in Chicago, 1870 - 2010', Review of Economics and Statistics, 100(5), 861-875.

Ahlfeldt, G. (2013). 'Urbanity.’ Discussion Paper No SERCDP0138, London; LSE.

Antwi, A.Y. and Adams, J. (2003). 'Rent-seeking Behaviour and its Economic Costs in Urban Land Transactions in Accra, Ghana’, Urban Studies, 40(10): 2083-2098. 
Arzaghi, M. and Henderson, J.V. (2008). 'Networking off Madison Avenue’, Review of Economic Studies, 75(4): 1011-1038.

Asabere, P., K., Hachey, G. and Grubaugh, S. (1989). 'Architecture, historic zoning, and the value of homes', The Journal of Real Estate Finance and Economics, 2(3): 181-195.

Ball, M. (2011). 'Planning Delay and the Responsiveness of English Housing Supply', Urban Studies, 48(2): 349-362.

Barr, J. (2013). Skyscrapers and Skylines: New York and Chicago, 1885-2007’, Journal of Regional Science, 53: 369-391.

Cheshire, P. C. and Hilber, C.A.L. (2008). ‘Office Space Supply Restrictions in Britain: The Political Economy of Market Revenge’, Economic Journal, 118(529): F185-F221.

Cheshire, P.C. and Sheppard, S. (2002). 'Welfare Economics of Land Use Regulation’, Journal of Urban Economics, 52(2): 242-296.

Cheshire, P.C., and Sheppard, S. (2005). 'The Introduction of Price Signals into Land Use Planning Decision-making: A Proposal', Urban Studies, 42(4): 647-663.

Cheshire, P.C., Hilber, C.A.L. and Kaplanis, I. (2015). 'Land Use Regulation and Productivity - Land Matters: Evidence from a UK Supermarket Chain’, Journal of Economic Geography, 15(1): 43-73.

City of London. (2010). 'City of London Tall Buildings Evidence Paper.'

City of London. (2012). 'City of London Protected Views: Supplementary Planning Document.'

Clapp, J.M. and Giacotto, C. (1999). 'Revisions in Repeat-Sales Price Indexes: Here Today, Gone Tomorrow?', Real Estate Economics, 27(1): 79-104.

Cullingworth, B.J. and Nadin, V. (2015). Town and Country Planning in the UK, Abingdon; Routledge, $13^{\text {th }}$ edition. 


$$
\begin{aligned}
& \text { "Trophy Architects" and design as rent-seeking: } \\
& \text { Quantifying deadweight losses in a tightly regulated office market }
\end{aligned}
$$

Department for Communities and Local Government. (2012). The National Planning Policy Framework, https://www.gov.uk/government/uploads/system/uploads/attachment_data/file/6077/2116950.pdf

Del Rosal, I. (2011). 'The Empirical Measurement of Rent-Seeking Costs’, Journal of Economic Surveys, 25(2): 298-325.

Dericks, G.H. (2013). London Office Performance: Determinants and Measurement of Capital Returns, PhD Thesis submitted to the London School of Economics.

Evans, A.W. (1988). No Room! No Room! The costs of the British town and country planning system, Occasional Paper No 79, London: Institute of Economic Affairs.

Fuerst, F., McAllister, P. and Murray, C. (2011). 'Designer Office Buildings: An Evaluation of the Price Impacts of Signature Architects', Environment and Planning A, 43(1): $166-184$.

Gat, D. (1998). 'Urban Focal Points and Design Quality Influence Rents: The Case of the Tel Aviv Office Market', Journal of Real Estate Research, 16(2): 229-247.

Glaeser, E.L., Gyourko, J. and Saks, R. (2005). 'Why Is Manhattan So Expensive? Regulation and the Rise in Housing Prices', Journal of Law and Economics, 48(2): 331-369.

Hilber, C.A.L. and Vermeulen. W. (2016). 'The Impact of Supply Constraints on House Prices in England', Economic Journal, 126(591): 358-405.

Hough, D., and Kratz, C. (1983). 'Can “Good” Architecture Meet the Market Test?’ Journal of Urban Economics, 14(1): 40-54.

House of Commons (2002). Tall Buildings: Sixteenth Report of Sessions 2001-02 Volume I. London: The Stationery Office Limited.

Inwood, S. (2005). City of Cities: The Birth of Modern London, London: MacMillan. 
Ioannidis, C. and Silver, M. (1999). 'Estimating Exact Hedonic Indexes: An Application to UK Television Sets', Journal of Economics, 69(1): 71-94.

Jennen, M. and Brounen, D. (2009). 'The Effect of Clustering on Office Rents: Evidence from the Amsterdam Market’, Real Estate Economics, 37(3): 185-208.

Kennedy, P. (1981). 'Estimation with Correctly Interpreted Dummy Variables in Semilogarithmic Equations’, American Economic Review, 71(4): 801.

Koster, H.R.A., van Ommeren, J. and Rietveld, P. (2014a). 'Agglomeration Economies and Productivity: A Structural Estimation Approach Using Commercial Rents’, Economica, 81: 63-85.

Koster, H.R.A., van Ommeren, J. and Rietveld, P. (2014b). 'Is the Sky the Limit? High-rise Buildings and Office Rents’, Journal of Economic Geography, 14(1): 125-153.

Koster, H.R.A. and Rouwendal, J. (2017). 'Historic Amenities and Housing Externalities: Evidence from the Netherlands’, Economic Journal, 127(605): F396-F420.

Krueger, A.O. (1974). 'The Political Economy of the Rent-Seeking Society’, American Economic Review, 64(3): 291-303.

Liu, C.H., Rosenthal, S.S. and Strange, W.C. (2018).’The Vertical City: Rent Gradients, Spatial Structure, and Agglomeration Economies.' Journal of Urban Economics, 106: 101-122: doi.org/10.1016/j.jue.2018.04.001.

Marriott, O. (1989). The Property Boom. Second Edition. London: Abingdon Publishing. Mayo, S. and Sheppard S.C. (2001). 'Housing Supply and the Effects of Stochastic Development Control', Journal of Housing Economics, 10(2): 109-128.

Nase, I., Berry, J. and Adair, A. (2013). 'Real Estate Value and Quality in Design in Commercial Office Properties’, Journal of European Real Estate Research, 6(1): 4862. 
Posner, R.A. (1975). 'The Social Costs of Monopoly and Regulation', Journal of Political Economy, 83(4): 807-27.

Sellar, I. (2015). 'Developing an icon - The Story of the Shard', Council on Tall Buildings and Urban Habitat, Conference Proceedings, New York. global.ctbuh.org/paper/2450

Sass, T.R and Pogodzinski, J.M. (1990). 'The Economic Theory of Zoning: A Critical Review’, Land Economics, 66(3): 294-314.

Tullock, G. (1967). 'The Welfare Costs of Tariffs, Monopolies and Theft', Western Economic Journal, 5(3): 224-32.

Turvey, R. (1998). 'Office Rents in the City of London, 1867-1910’, The London Journal, 23(2): 53-67.

Vandell, K. and Lane, J. (1989). ‘The Economics of Architecture and Urban Design’, Journal of the American Real Estate and Urban Economics Association, 17(2): 235-260.

Wheaton, W.C., Torto, R.G. and Evans, P. (1997). 'The Cyclic Behavior of the Greater London Office Market', The Journal of Real Estate Finance and Economics, 15(1): 7792. 
TABLES

Table 1: Descriptive statistics of data used in building size regressions

\begin{tabular}{|c|c|c|c|c|c|c|}
\hline & $\mathbf{N}$ & Mean & Median & St. Dev. & Maximum & Minimum \\
\hline TA Bldg & 105 & & & & & \\
\hline Modern TA & 64 & & & & & \\
\hline Pre-Modern TA & 41 & & & & & \\
\hline Modern TA Bldg Built outside HPA & 27 & & & & & \\
\hline Floorspace $\left(\mathrm{m}^{2}\right)$ & 2,039 & 6,252 & 2,262 & 11,189 & 113,665 & 150 \\
\hline Floors (All buildings) & 2,039 & 7.57 & 7 & 4.49 & 90 & 3 \\
\hline Floors (Standard architect only) & 2,039 & & & & & \\
\hline Footprint $\left(\mathrm{m}^{2}\right)$ & 2,039 & 1,139 & 816 & 1,477 & 16,266 & 50 \\
\hline Site area $\left(\mathrm{m}^{2}\right)$ & 2,039 & 1,283 & 913 & 1,795 & 22,129 & 53 \\
\hline Floorspace/site area & 2,039 & 4.29 & 3.90 & 2.53 & 26.02 & 0.22 \\
\hline Footprint/site area & 2,039 & 0.95 & 1.00 & 0.13 & 1.00 & 0.09 \\
\hline Average Employment 600m & 2,039 & 41,564 & 36,547 & 30,300 & 129,947 & 0 \\
\hline Built in HPA & 598 & & & & & \\
\hline Listed & 386 & & & & & \\
\hline
\end{tabular}

Distribution of Sample by Decade built and Local Planning Authority

\begin{tabular}{|c|c|c|c|c|c|c|c|c|c|c|}
\hline Decade Built & $\underline{\text { Pre- } 1950}$ & $\underline{1950 \mathrm{~s}}$ & $\underline{1960 \mathrm{~s}}$ & $\underline{1970 \mathrm{~s}}$ & $\underline{1980 \mathrm{~s}} \underline{1990 \mathrm{~s}}$ & $\underline{2000 \mathrm{~s}} 2010 \mathrm{~s}$ & & & & \\
\hline No. & 977 & 92 & 106 & 121 & $263 \quad 194$ & $187 \quad 99$ & & & & \\
\hline LPA & Camden & $\begin{array}{l}\text { City of } \\
\text { London }\end{array}$ & Westminster & Hackney & Hammersmith & Islington & Kensington & Lambeth Southwark & $\begin{array}{l}\text { Tower } \\
\text { Hamlets }\end{array}$ & Docklands Wandsworth \\
\hline Jo. & 260 & 495 & 736 & 61 & 45 & 165 & 48 & 128 & 43 & 37 \\
\hline
\end{tabular}

Table 2: Descriptive statistics of data used in hedonic regressions

\begin{tabular}{|c|c|c|c|c|c|c|}
\hline & $\mathbf{N}$ & Mean & Median & St. Dev. & Maximum & Minimum \\
\hline TA Bldg & 186 & & & & & \\
\hline Modern TA & 65 & & & & & \\
\hline Pre-Modern TA & 121 & & & & & \\
\hline Modern TA Bldg Built outside HPA & 26 & & & & & \\
\hline Price $(£ m)$ & 2,739 & 55.56 & 22.00 & 97.11 & $1,285.50$ & 0.42 \\
\hline Price $(£) /$ Floorspace $\left(\mathrm{m}^{2}\right)$ & 2,739 & 9,084 & 7,568 & 7,169 & 93,287 & 509 \\
\hline Price $(£) /$ Site area $\left(\mathrm{m}^{2}\right)$ & 2,739 & 40,206 & 30,777 & 36,189 & 453,932 & 627 \\
\hline Floorspace $\left(\mathrm{m}^{2}\right)$ & 2,739 & 6,805 & 2,967 & 10,522 & 113,665 & 151 \\
\hline Floors & 2,739 & 7.81 & 7.00 & 4.12 & 55 & 3 \\
\hline Footprint $\left(\mathrm{m}^{2}\right)$ & 2,739 & 1,243 & 966 & 1,460 & 16,266 & 50 \\
\hline Site area $\left(\mathrm{m}^{2}\right)$ & 2,739 & 1,393 & 1,077 & 1,719 & 16,266 & 53 \\
\hline Floorspace/site area & 2,739 & 4.50 & 4.11 & 2.65 & 28.17 & 0.22 \\
\hline Footprint/site area & 2,739 & 0.94 & 1.00 & 0.13 & 1.00 & 0.09 \\
\hline Employment Density 600m & 2,739 & 47,832 & 42,332 & 33,750 & 144,386 & 0 \\
\hline Sold while in HPA & 2,105 & & & & & \\
\hline Built in HPA & 838 & & & & & \\
\hline Listed & 462 & & & & & \\
\hline
\end{tabular}

Distribution of Sample between Decade built, Year Sold, Local Planning Authority, and Submarket

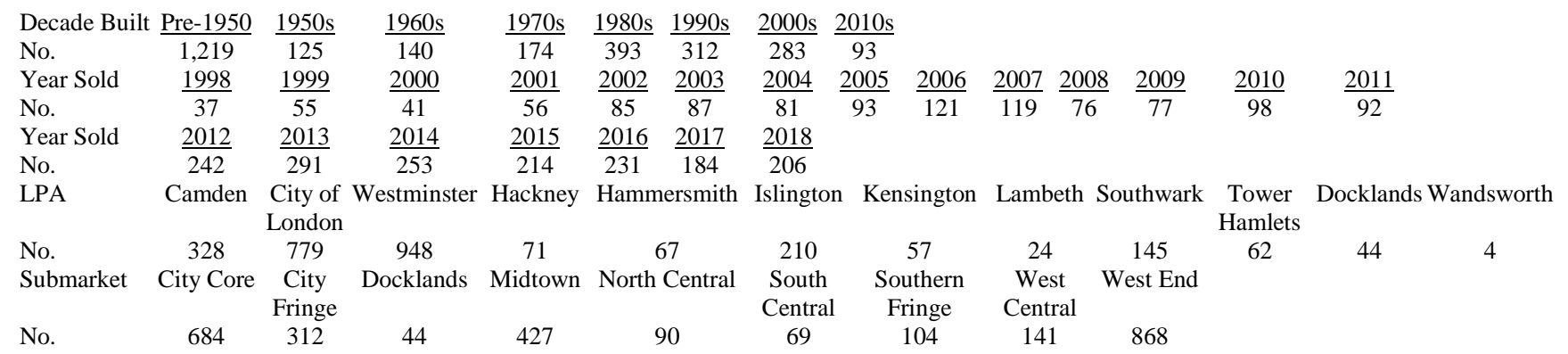


Table 3: Can TAs build bigger? Dep. Var.: Total floorspace/ site area

\begin{tabular}{|c|c|c|c|c|c|}
\hline VARIABLES & $\begin{array}{c}(1) \\
\text { Floorspace/ } \\
\text { Site area } \\
\end{array}$ & $\begin{array}{c}(2) \\
\text { Floorspace/ } \\
\text { Site area } \\
\end{array}$ & $\begin{array}{c}\text { (3) } \\
\text { Floorspace/ } \\
\text { Site area } \\
\end{array}$ & $\begin{array}{c}(4) \\
\text { Floorspace/ } \\
\text { Site area } \\
\end{array}$ & $\begin{array}{c}(5) \\
\text { Floorspace/ } \\
\text { Site area } \\
\end{array}$ \\
\hline Modern TA outside HPA & & $\begin{array}{c}7.193 * * * \\
(1.307)\end{array}$ & $\begin{array}{c}6.332 * * * \\
(1.287)\end{array}$ & $\begin{array}{c}5.565^{* * *} \\
(1.204)\end{array}$ & $\begin{array}{c}5.422 * * * \\
(1.192)\end{array}$ \\
\hline TA & $\begin{array}{c}1.940 * * * \\
(0.479)\end{array}$ & $\begin{array}{c}0.0884 \\
(0.211)\end{array}$ & $\begin{array}{c}-0.0640 \\
(0.208)\end{array}$ & $\begin{array}{c}-0.0124 \\
(0.207)\end{array}$ & $\begin{array}{c}-0.0116 \\
(0.210)\end{array}$ \\
\hline Built in HPA & $\begin{array}{c}0.432 * * * \\
(0.118)\end{array}$ & $\begin{array}{c}0.531^{* * *} \\
(0.112)\end{array}$ & $\begin{array}{l}-0.141 \\
(0.170)\end{array}$ & $\begin{array}{c}0.167 \\
(0.160)\end{array}$ & $\begin{array}{c}0.0758 \\
(0.157)\end{array}$ \\
\hline Average Office Permission Refusal Rate & $\begin{array}{c}-10.39 * * * \\
(0.985)\end{array}$ & $\begin{array}{c}-10.31 * * * \\
(0.956)\end{array}$ & $\begin{array}{c}-10.10^{* * *} \\
(0.940)\end{array}$ & $\begin{array}{c}-8.335 * * * \\
(2.064)\end{array}$ & $\begin{array}{c}-7.448 * * * \\
(2.029)\end{array}$ \\
\hline Decade Built & NO & NO & YES & YES & YES \\
\hline City of London & & & & $\begin{array}{c}0.257 \\
(0.270)\end{array}$ & $\begin{array}{c}-1.025^{* * *} \\
(0.296)\end{array}$ \\
\hline Docklands & & & & $\begin{array}{c}3.796 * * * \\
(0.857)\end{array}$ & $\begin{array}{c}3.727 * * * \\
(0.827)\end{array}$ \\
\hline Average Employment 600m & & & & & $\begin{array}{c}2.44 \mathrm{e}-05^{* * * *} \\
(2.77 \mathrm{e}-06)\end{array}$ \\
\hline Constant & $\begin{array}{c}5.074 * * * \\
(0.124)\end{array}$ & $\begin{array}{c}5.037 * * * \\
(0.121)\end{array}$ & $\begin{array}{c}4.803 * * * \\
(0.121)\end{array}$ & $\begin{array}{c}4.574 * * * \\
(0.265)\end{array}$ & $\begin{array}{c}3.749 * * * \\
(0.279)\end{array}$ \\
\hline Observations & 2,039 & 2,039 & 2,039 & 2,039 & 2,039 \\
\hline R-squared & 0.095 & 0.174 & 0.206 & 0.239 & 0.269 \\
\hline
\end{tabular}

Robust standard errors in parentheses

$* * * \mathrm{p}<0.01, * * \mathrm{p}<0.05, * \mathrm{p}<0.1$ 
Table 4: Can TAs build taller? Dep. Var.: No. of floors above ground level

\begin{tabular}{|c|c|c|c|}
\hline VARIABLES & $\begin{array}{c}(1) \\
\text { Floors }\end{array}$ & $\begin{array}{c}(2) \\
\text { Floors }\end{array}$ & $\begin{array}{c}(3) \\
\text { Floors }\end{array}$ \\
\hline Modern TA outside HPA & $\begin{array}{c}15.50 * * * \\
(3.509)\end{array}$ & $\begin{array}{c}14.43 * * * \\
(3.505)\end{array}$ & $\begin{array}{c}14.29 * * * \\
(3.512)\end{array}$ \\
\hline TA & $\begin{array}{c}0.882 * * * \\
(0.327)\end{array}$ & $\begin{array}{c}0.951 * * * \\
(0.329)\end{array}$ & $\begin{array}{c}0.952 * * * \\
(0.334)\end{array}$ \\
\hline Built in HPA & $\begin{array}{c}-1.157 * * * \\
(0.350)\end{array}$ & $\begin{array}{c}-0.725^{* *} \\
(0.325)\end{array}$ & $\begin{array}{c}-0.818 * * \\
(0.326)\end{array}$ \\
\hline Average Office Permission Refusal Rate & $\begin{array}{c}-13.26 * * * \\
(1.555)\end{array}$ & $\begin{array}{c}-11.32 * * * \\
(3.359)\end{array}$ & $\begin{array}{c}-10.42^{* * *} \\
(3.355)\end{array}$ \\
\hline Decade Built & YES & YES & YES \\
\hline City of London & & $\begin{array}{c}0.284 \\
(0.453)\end{array}$ & $\begin{array}{c}-1.019 * * \\
(0.476)\end{array}$ \\
\hline Docklands & & $\begin{array}{c}5.297 * * * \\
(1.777)\end{array}$ & $\begin{array}{c}5.227 * * * \\
(1.756)\end{array}$ \\
\hline Average Employment 600m & & & $\begin{array}{c}2.48 \mathrm{e}-05^{* * *} \\
(4.38 \mathrm{e}-06)\end{array}$ \\
\hline Constant & $\begin{array}{c}7.730 * * * \\
(0.169)\end{array}$ & $\begin{array}{c}7.477 * * * \\
(0.418)\end{array}$ & $\begin{array}{c}6.639 * * * \\
(0.448)\end{array}$ \\
\hline Observations & 2,039 & 2,039 & 2,039 \\
\hline R-squared & 0.331 & 0.351 & 0.361 \\
\hline
\end{tabular}

Robust standard errors in parentheses

${ }^{* * *} \mathrm{p}<0.01,{ }^{* *} \mathrm{p}<0.05,{ }^{*} \mathrm{p}<0.1$ 
Table 5: Can TAs get a bigger building footprint? Dep. Var.: Footprint/ site area

\begin{tabular}{|c|c|c|c|c|}
\hline VARIABLES & $\begin{array}{c}\text { (1) } \\
\text { Footprint/ } \\
\text { Site area }\end{array}$ & $\begin{array}{c}(2) \\
\text { Footprint/ } \\
\text { Site area }\end{array}$ & $\begin{array}{c}\text { (3) } \\
\text { Footprint/ } \\
\text { Site area }\end{array}$ & $\begin{array}{c}\text { (4) } \\
\text { Footprint/ } \\
\text { Site area }\end{array}$ \\
\hline Modern TA outside HPA & $\begin{array}{c}0.107 \\
(0.0682)\end{array}$ & $\begin{array}{c}0.103 \\
(0.0706)\end{array}$ & $\begin{array}{c}0.0944 \\
(0.0718)\end{array}$ & $\begin{array}{c}0.139 * \\
(0.0767)\end{array}$ \\
\hline TA & $\begin{array}{c}-0.0618 * * * \\
(0.0143)\end{array}$ & $\begin{array}{c}-0.0624 * * * \\
(0.0142)\end{array}$ & $\begin{array}{c}-0.0624 * * * \\
(0.0138)\end{array}$ & $\begin{array}{c}-0.0594 * * * \\
(0.0139)\end{array}$ \\
\hline Built in HPA & $\begin{array}{l}0.0535 * * * \\
(0.00878)\end{array}$ & $\begin{array}{l}0.0571 * * * \\
(0.00939)\end{array}$ & $\begin{array}{c}0.0519 * * * \\
(0.00921)\end{array}$ & $\begin{array}{c}0.0494 * * * \\
(0.00917)\end{array}$ \\
\hline Average Office Permission Refusal Rate & $\begin{array}{c}-0.290 * * * \\
(0.0590)\end{array}$ & $\begin{array}{c}-0.489 * * * \\
(0.176)\end{array}$ & $\begin{array}{c}-0.438 * * \\
(0.171)\end{array}$ & $\begin{array}{c}-0.471^{* * *} \\
(0.168)\end{array}$ \\
\hline Built 1950s & $\begin{array}{l}-0.0225^{*} \\
(0.0133)\end{array}$ & $\begin{array}{l}-0.0211 \\
(0.0133)\end{array}$ & $\begin{array}{l}-0.0134 \\
(0.0130)\end{array}$ & $\begin{array}{l}-0.0106 \\
(0.0130)\end{array}$ \\
\hline Built 1960s & $\begin{array}{c}-0.0782^{* * * *} \\
(0.0189)\end{array}$ & $\begin{array}{c}-0.0781^{* * *} \\
(0.0190)\end{array}$ & $\begin{array}{c}-0.0731^{* * *} \\
(0.0189)\end{array}$ & $\begin{array}{c}-0.0615^{* * *} \\
(0.0177)\end{array}$ \\
\hline Built 1970s & $\begin{array}{c}-0.0537 * * * \\
(0.0142)\end{array}$ & $\begin{array}{c}-0.0532 * * * \\
(0.0142)\end{array}$ & $\begin{array}{c}-0.0484 * * * \\
(0.0140)\end{array}$ & $\begin{array}{c}-0.0418 * * * \\
(0.0136)\end{array}$ \\
\hline Built 1980s & $\begin{array}{c}-0.0763 * * * \\
(0.0124)\end{array}$ & $\begin{array}{c}-0.0773 * * * \\
(0.0124)\end{array}$ & $\begin{array}{c}-0.0696 * * * \\
(0.0121)\end{array}$ & $\begin{array}{c}-0.0668 * * * \\
(0.0121)\end{array}$ \\
\hline Built 1990s & $\begin{array}{c}-0.0605^{* * *} \\
(0.0119)\end{array}$ & $\begin{array}{c}-0.0636 * * * \\
(0.0127)\end{array}$ & $\begin{array}{c}-0.0562 * * * \\
(0.0124)\end{array}$ & $\begin{array}{c}-0.0519 * * * \\
(0.0126)\end{array}$ \\
\hline Built 2000s & $\begin{array}{c}-0.0483 * * * \\
(0.0117)\end{array}$ & $\begin{array}{c}-0.0513 * * * \\
(0.0124)\end{array}$ & $\begin{array}{c}-0.0447 * * * \\
(0.0123)\end{array}$ & $\begin{array}{c}-0.0360 * * * \\
(0.0123)\end{array}$ \\
\hline Built 2010s & $\begin{array}{l}-0.0233 \\
(0.0174)\end{array}$ & $\begin{array}{l}-0.0229 \\
(0.0175)\end{array}$ & $\begin{array}{l}-0.0126 \\
(0.0180)\end{array}$ & $\begin{array}{l}0.00141 \\
(0.0198)\end{array}$ \\
\hline City of London & & $\begin{array}{l}-0.0286 \\
(0.0199)\end{array}$ & $\begin{array}{c}-0.102 * * * \\
(0.0232)\end{array}$ & $\begin{array}{c}-0.105^{* * *} \\
(0.0229)\end{array}$ \\
\hline Docklands & & $\begin{array}{c}0.0296 \\
(0.0255)\end{array}$ & $\begin{array}{c}0.0257 \\
(0.0250)\end{array}$ & $\begin{array}{c}0.0420 \\
(0.0274)\end{array}$ \\
\hline Average Employment 600m & & & $\begin{array}{c}1.40 \mathrm{e}-06 * * * \\
(1.78 \mathrm{e}-07)\end{array}$ & $\begin{array}{c}1.47 \mathrm{e}-06 * * * \\
(1.77 \mathrm{e}-07)\end{array}$ \\
\hline Floors & & & & $\begin{array}{c}-0.00313^{* *} \\
(0.00128)\end{array}$ \\
\hline Constant & $\begin{array}{l}0.993 * * * \\
(0.00661)\end{array}$ & $\begin{array}{c}1.018^{* * *} \\
(0.0209)\end{array}$ & $\begin{array}{c}0.971 * * * \\
(0.0202)\end{array}$ & $\begin{array}{c}0.991 * * * \\
(0.0211)\end{array}$ \\
\hline Observations & 2,039 & 2,039 & 2,039 & 2,039 \\
\hline R-squared & 0.061 & 0.064 & 0.100 & 0.107 \\
\hline
\end{tabular}

Robust standard errors in parentheses $\quad{ }^{* * *} \mathrm{p}<0.01,{ }^{* *} \mathrm{p}<0.05,{ }^{*} \mathrm{p}<0.1$ 
Table 6: What do TAs yield in price of building?

\begin{tabular}{|c|c|c|c|c|}
\hline VARIABLE & $\begin{array}{c}(1) \\
\ln (\text { price) }\end{array}$ & $\begin{array}{c}(2) \\
\ln \text { (price) }\end{array}$ & $\begin{array}{c}(3) \\
\ln (\text { price) }\end{array}$ & $\begin{array}{c}(4) \\
\ln (\text { price) }\end{array}$ \\
\hline TA & $\begin{array}{c}0.158 * * * \\
(0.0393)\end{array}$ & & $\begin{array}{c}0.138^{* * * *} \\
(0.0395)\end{array}$ & \\
\hline Modern TA & & $\begin{array}{c}0.223 * * * \\
(0.0647)\end{array}$ & & $\begin{array}{l}0.167 * * \\
(0.0665)\end{array}$ \\
\hline Pre-Modern TA & & $\begin{array}{l}0.123^{* *} \\
(0.0484)\end{array}$ & & $\begin{array}{c}0.125^{* * *} \\
(0.0482)\end{array}$ \\
\hline Sold while in HPA & $\begin{array}{c}0.0809 * * * \\
(0.0246)\end{array}$ & $\begin{array}{c}0.0813^{* * *} * \\
(0.0246)\end{array}$ & $\begin{array}{c}0.0889 * * * \\
(0.0246)\end{array}$ & $\begin{array}{c}0.0892 * * * \\
(0.0246)\end{array}$ \\
\hline Listed & $\begin{array}{c}0.0545^{* *} \\
(0.0272)\end{array}$ & $\begin{array}{c}0.0596^{* * *} \\
(0.0275)\end{array}$ & $\begin{array}{l}0.0520^{*} \\
(0.0271)\end{array}$ & $\begin{array}{l}0.0539 * * \\
(0.0275)\end{array}$ \\
\hline Ln(Office Permission Refusal Rate 9yr Moving Average) & $\begin{array}{c}0.0441^{* * *} \\
(0.0105)\end{array}$ & $\begin{array}{c}0.0437^{* * * *} \\
(0.0105)\end{array}$ & $\begin{array}{c}0.0434 * * * * \\
(0.0105)\end{array}$ & $\begin{array}{c}0.0433^{* * *} * \\
(0.0105)\end{array}$ \\
\hline Ln(Employment 600m) & $\begin{array}{c}0.168^{* * *} \\
(0.0158)\end{array}$ & $\begin{array}{c}0.167 * * * \\
(0.0158)\end{array}$ & $\begin{array}{c}0.173^{* * *} \\
(0.0159)\end{array}$ & $\begin{array}{l}0.172 * * * \\
(0.0159)\end{array}$ \\
\hline Ln(Listed Building Density 300m) & $\begin{array}{c}0.0332 * * * \\
(0.00780)\end{array}$ & $\begin{array}{c}0.0338^{* * *} \\
(0.00783)\end{array}$ & $\begin{array}{c}0.0341^{* * * *} \\
(0.00779)\end{array}$ & $\begin{array}{c}0.0342 * * * \\
(0.00781)\end{array}$ \\
\hline Office Grade A/B & $\begin{array}{c}0.0656 * * \\
(0.0313)\end{array}$ & $\begin{array}{c}0.0660 * * \\
(0.0313)\end{array}$ & $\begin{array}{c}0.0672^{* *} \\
(0.0312)\end{array}$ & $\begin{array}{c}0.0680^{* *} \\
(0.0313)\end{array}$ \\
\hline Office Grade A & $\begin{array}{c}0.214 * * * \\
(0.0348)\end{array}$ & $\begin{array}{c}0.214 * * * \\
(0.0348)\end{array}$ & $\begin{array}{c}0.213 * * * \\
(0.0347)\end{array}$ & $\begin{array}{c}0.214 * * * \\
(0.0347)\end{array}$ \\
\hline Ln(Percent Occupied) & $\begin{array}{c}0.0271^{* * *} \\
(0.00520)\end{array}$ & $\begin{array}{c}0.0272 * * * \\
(0.00520)\end{array}$ & $\begin{array}{c}0.0277 * * * \\
(0.00518)\end{array}$ & $\begin{array}{c}0.0277 * * * \\
(0.00518)\end{array}$ \\
\hline Ln(Floorspace $m^{2}$ ) & $\begin{array}{c}0.947 * * * \\
(0.00941)\end{array}$ & $\begin{array}{l}0.945^{* * *} \\
(0.00944)\end{array}$ & $\begin{array}{l}0.933 * * * \\
(0.00998)\end{array}$ & $\begin{array}{l}0.933^{* * *} \\
(0.01000)\end{array}$ \\
\hline Floors 11-20 & & & $\begin{array}{c}0.127 * * * \\
(0.0374)\end{array}$ & $\begin{array}{c}0.127 * * * \\
(0.0375)\end{array}$ \\
\hline Floors 21-30 & & & $\begin{array}{l}0.00731 \\
(0.0986)\end{array}$ & $\begin{array}{l}0.00438 \\
(0.0988)\end{array}$ \\
\hline Floors 31+ & & & $\begin{array}{c}0.459 * * * \\
(0.125)\end{array}$ & $\begin{array}{c}0.445^{* * * *} \\
(0.128)\end{array}$ \\
\hline Decade Build & YES & YES & YES & YES \\
\hline Submarket & YES & YES & YES & YES \\
\hline Year Sold & YES & YES & YES & YES \\
\hline Constant & $\begin{array}{c}-7.723^{* * *} \\
(0.245)\end{array}$ & $\begin{array}{c}-7.713^{* * *} \\
(0.245)\end{array}$ & $\begin{array}{c}-7.694 * * * \\
(0.246)\end{array}$ & $\begin{array}{c}-7.687 * * * \\
(0.246)\end{array}$ \\
\hline Observations & 2,739 & 2,739 & 2,739 & 2,739 \\
\hline R-squared & 0.880 & 0.880 & 0.881 & 0.881 \\
\hline
\end{tabular}

Standard errors in parentheses

$* * * \mathrm{p}<0.01, * * \mathrm{p}<0.05, * \mathrm{p}<0.1$ 
Table 7: What value does a TA add to a site? Dep. var.: $\ln \left(\right.$ price/site area $\mathbf{m}^{2}$ )

\begin{tabular}{|c|c|c|c|}
\hline VARIABLES & $\begin{array}{c}(1) \\
\text { Ln(Price/ } \\
\text { Site area) } \\
\end{array}$ & $\begin{array}{c}\text { (2) } \\
\text { Ln(Price/ } \\
\text { Site area) } \\
\end{array}$ & $\begin{array}{c}\text { (3) } \\
\text { Ln(Price/ } \\
\text { Site area) }\end{array}$ \\
\hline Modern TA outside HPA & $\begin{array}{c}0.736 * * * \\
(0.206)\end{array}$ & $\begin{array}{c}0.771 * * * \\
(0.202)\end{array}$ & $\begin{array}{c}0.774 * * * \\
(0.151)\end{array}$ \\
\hline Modern TA & $\begin{array}{l}0.270 * * * \\
(0.0702)\end{array}$ & $\begin{array}{l}0.173 * * \\
(0.0753)\end{array}$ & $\begin{array}{l}0.149 * * \\
(0.0685)\end{array}$ \\
\hline Pre-Modern TA & $\begin{array}{l}0.213^{* *} \\
(0.0919)\end{array}$ & $\begin{array}{l}0.222 * * \\
(0.0929)\end{array}$ & $\begin{array}{c}0.157^{*} \\
(0.0911)\end{array}$ \\
\hline Sold while in HPA & $\begin{array}{c}0.0405 \\
(0.0351)\end{array}$ & $\begin{array}{c}0.0494 \\
(0.0346)\end{array}$ & $\begin{array}{c}0.0306 \\
(0.0334)\end{array}$ \\
\hline Listed & $\begin{array}{c}-0.0204 \\
(0.0410)\end{array}$ & $\begin{array}{l}0.00621 \\
(0.0417)\end{array}$ & $\begin{array}{c}-0.0801^{* *} \\
(0.0396)\end{array}$ \\
\hline Ln(Office Permission Refusal Rate 9yr Moving Average) & $\begin{array}{c}0.0446 * * * \\
(0.0158)\end{array}$ & $\begin{array}{c}0.0473 * * * \\
(0.0161)\end{array}$ & $\begin{array}{l}0.0239 * \\
(0.0136)\end{array}$ \\
\hline Ln(Employment 600m) & $\begin{array}{c}0.246 * * * \\
(0.0442)\end{array}$ & $\begin{array}{c}0.247 * * * \\
(0.0448)\end{array}$ & $\begin{array}{c}0.238 * * * \\
(0.0711)\end{array}$ \\
\hline Ln(Listed Building Density 300m) & $\begin{array}{c}0.0899 * * * \\
(0.0129)\end{array}$ & $\begin{array}{c}0.0899 * * * * \\
(0.0128)\end{array}$ & $\begin{array}{c}0.0558 * * * \\
(0.0121)\end{array}$ \\
\hline Office Grade A/B & $\begin{array}{l}0.115^{* *} \\
(0.0454)\end{array}$ & $\begin{array}{l}0.103^{* *} \\
(0.0456)\end{array}$ & $\begin{array}{c}0.167 * * * \\
(0.0414)\end{array}$ \\
\hline Office Grade A & $\begin{array}{c}0.564 * * * \\
(0.0486)\end{array}$ & $\begin{array}{c}0.520 * * * \\
(0.0510)\end{array}$ & $\begin{array}{c}0.490 * * * \\
(0.0461)\end{array}$ \\
\hline Ln(Percent Occupied) & $\begin{array}{c}0.0455^{* * *} \\
(0.00873)\end{array}$ & $\begin{array}{c}0.0449 * * * \\
(0.00868)\end{array}$ & $\begin{array}{c}0.0463 * * * \\
(0.00801)\end{array}$ \\
\hline Decade Built & NO & YES & YES \\
\hline Submarket & NO & NO & YES \\
\hline Year Sold & YES & YES & YES \\
\hline Constant & $\begin{array}{c}6.120 * * * \\
(0.425)\end{array}$ & $\begin{array}{c}6.107 * * * \\
(0.431)\end{array}$ & $\begin{array}{c}6.106^{* * * *} \\
(0.775)\end{array}$ \\
\hline Observations & 2,739 & 2,739 & 2,739 \\
\hline R-squared & 0.356 & 0.360 & 0.451 \\
\hline
\end{tabular}

Robust standard errors in parentheses *** $\mathrm{p}<0.01,{ }^{* *} \mathrm{p}<0.05, * \mathrm{p}<0.1$ 
Table 8: The impact on building heights of gaining TA status in London compared to Chicago

\begin{tabular}{|c|c|c|c|c|}
\hline VARIABLES & $\begin{array}{l}(1) \\
\text { Floors }\end{array}$ & $\begin{array}{l}(2) \\
\text { Floors }\end{array}$ & $\begin{array}{c}(3) \\
\text { Floors } \\
\text { Omit } 1 \text { Canada } \\
\text { Square } \\
\end{array}$ & $\begin{array}{c}(4) \\
\text { Floors } \\
\text { Omit } 1 \text { Canada } \\
\text { Square }\end{array}$ \\
\hline Modern TA outside HPA & $\begin{array}{c}13.12^{* * * *} \\
(3.735)\end{array}$ & $\begin{array}{c}8.719 * * \\
(3.895)\end{array}$ & $\begin{array}{c}14.37 * * * \\
(3.536)\end{array}$ & $\begin{array}{c}10.82^{* * *} \\
(3.141)\end{array}$ \\
\hline Chicago TA & $\begin{array}{l}-7.156 \\
(6.414)\end{array}$ & $\begin{array}{l}-4.400 \\
(7.604)\end{array}$ & $\begin{array}{c}-8.259 \\
(6.341)\end{array}$ & $\begin{array}{l}-6.430 \\
(7.499)\end{array}$ \\
\hline TA & $\begin{array}{c}0.209 \\
(1.644)\end{array}$ & $\begin{array}{l}-1.303 \\
(2.309)\end{array}$ & $\begin{array}{c}1.367 \\
(1.223)\end{array}$ & $\begin{array}{c}0.320 \\
(1.572)\end{array}$ \\
\hline Built in HPA & $\begin{array}{l}-1.344 \\
(2.004)\end{array}$ & $\begin{array}{l}-5.046 \\
(3.598)\end{array}$ & $\begin{array}{c}0.421 \\
(0.930)\end{array}$ & $\begin{array}{l}-2.223 \\
(2.051)\end{array}$ \\
\hline Chicago & $\begin{array}{c}32.23^{* * *} \\
(5.773)\end{array}$ & $\begin{array}{c}27.28^{* * *} \\
(6.494)\end{array}$ & $\begin{array}{c}34.58 * * * \\
(5.266)\end{array}$ & $\begin{array}{c}31.57 * * * \\
(5.071)\end{array}$ \\
\hline $\begin{array}{l}\text { Decade Built } \\
\text { Constant }\end{array}$ & $\begin{array}{c}\mathrm{NO} \\
7.617^{* * *} \\
(2.510)\end{array}$ & $\begin{array}{l}\text { YES } \\
4.429 * * * \\
(0.785)\end{array}$ & $\begin{array}{c}\mathrm{NO} \\
5.208 * * * \\
(0.653)\end{array}$ & $\begin{array}{c}\text { YES } \\
4.429 * * * \\
(0.786)\end{array}$ \\
\hline $\begin{array}{l}\text { Observations } \\
\text { R-squared }\end{array}$ & $\begin{array}{c}87 \\
0.474\end{array}$ & $\begin{array}{c}87 \\
0.505\end{array}$ & $\begin{array}{c}86 \\
0.516\end{array}$ & $\begin{array}{c}86 \\
0.539\end{array}$ \\
\hline
\end{tabular}

Robust standard errors in parentheses *** $\mathrm{p}<0.01, * * \mathrm{p}<0.05, * \mathrm{p}<0.1$

Table 9: SA and TA height and surpluses according to Gardiner \& Theobald (G\&T) and Ahlfeldt \& McMillen (A\&M)

\begin{tabular}{|c|c|c|c|c|c|}
\hline Standard Architect & & & & & \\
\hline Method & G\&T & G\&T & $\mathrm{A} \& \mathrm{M}$ & $\begin{array}{l}\text { Max Surplus } \\
\text { G\&T }\end{array}$ & $\begin{array}{l}\text { Max Surplus } \\
\text { A\&M }\end{array}$ \\
\hline Floors & 8 & 22 & 22 & 117 & 117 \\
\hline Net Internal Area & 10,203 & 26,853 & 23,854 & 110,649 & 109,327 \\
\hline Total Costs & $32,814,237$ & $104,856,390$ & $46,177,432$ & $766,214,185$ & $477,863,151$ \\
\hline Sale Price & $142,848,000$ & $375,936,000$ & $333,952,084$ & $1,549,080,000$ & $1,530,574,297$ \\
\hline Surplus & $110,033,763$ & $271,079,610$ & $287,774,652$ & $782,865,815$ & $1,052,711,145$ \\
\hline \multicolumn{6}{|l|}{ Trophy Architect } \\
\hline Method & G\&T & G\&T & A\&M & $\begin{array}{l}\text { Max Surplus } \\
\text { G\&T }\end{array}$ & $\begin{array}{l}\text { Max Surplus } \\
\text { A\&M }\end{array}$ \\
\hline Floors & 8 & 22 & 22 & 122 & 119 \\
\hline Net Internal Area & 10,203 & 26,853 & 23,854 & 113,634 & 111,028 \\
\hline Total Costs & $37,048,054$ & $118,516,283$ & $52,159,705$ & $913,942,603$ & $567,658,681$ \\
\hline Sale Price & $168,811,233$ & $444,263,971$ & $394,649,300$ & $1,880,029,226$ & $1,836,908,637$ \\
\hline Surplus & $131,763,179$ & $325,747,688$ & $342,489,595$ & $966,086,623$ & $1,269,249,955$ \\
\hline
\end{tabular}




\section{MAPS \& FIGURES}

Figure 1: The 546 postcode sectors and 2,039 office locations 
Figure 3 here: Price per $\mathbf{m}^{2}$ and construction costs for representative TA building in City

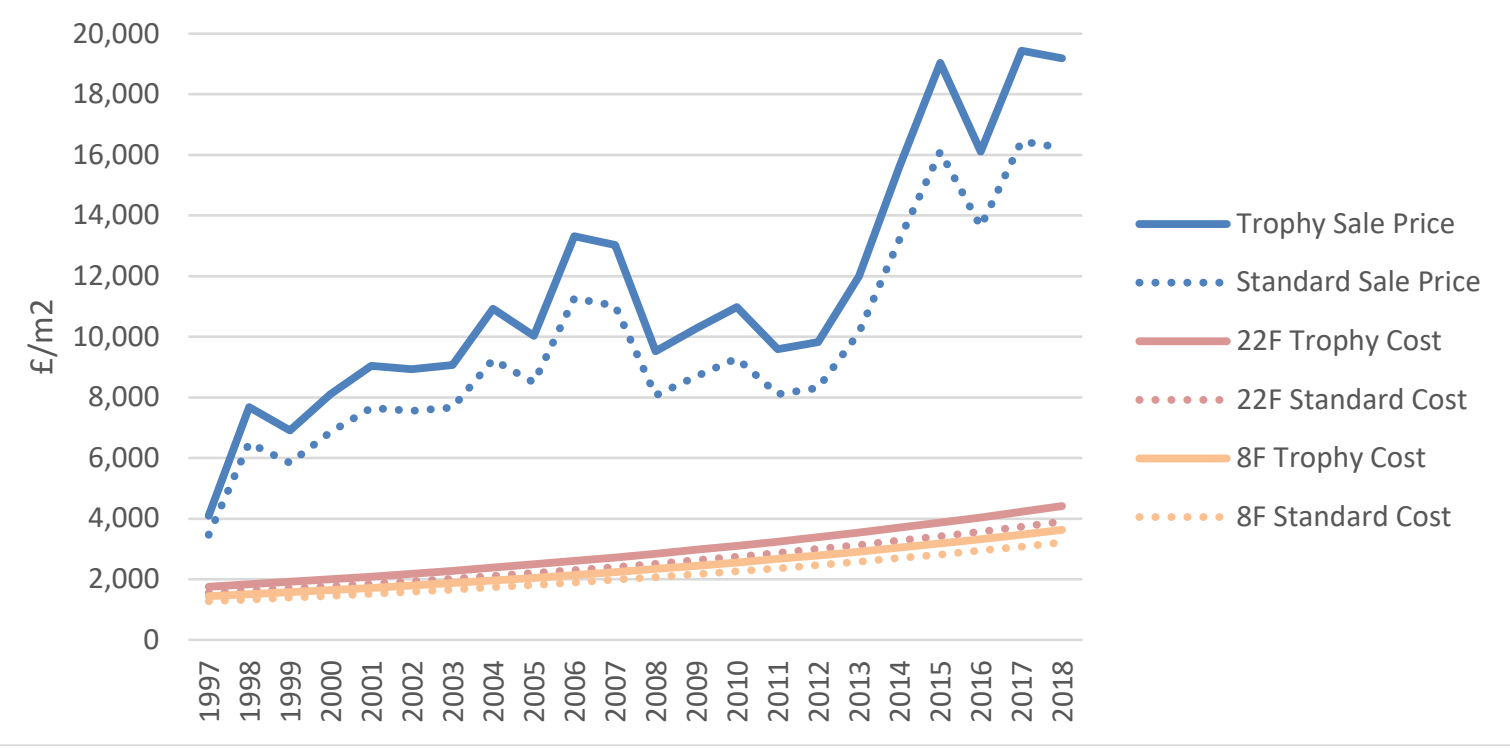

\section{For Online Publication only}

Appendix I: Estates Gazette's London Office Submarket Definitions by Postcode District

City Core: EC1A, EC2M, EC2N, EC2R, EC2Y, EC2V, EC2A (only Finsbury Pavement, Finsbury Square, Appold Street and Chiswell Street), EC3, EC4 (excluding EC4A \& EC4Y) City Fringe: EC1M, EC1N (excluding postcode sector 2), EC1R, EC1V, EC1Y, EC2A (excluding Finsbury Pavement, Finsbury Square, Appold Street and Chiswell Street), E1 Southbank: SE1 postcode sectors 0, 1, 2 \& 9

Docklands: E14

Midtown: EC4A \& EC4Y, EC1N (sector 2), WC1, WC2 (excluding Leicester Square)

West End: W1, SW1, NW1 sectors 2 (Euston Road only), 3, 5 \& 6, Leicester Square (WC2) and W2 sectors 1,2 \& 6

South Central: Remainder of SE1 and all of SE11

North Central: Remainder of NW1 and N1 and all of E8

West Central: Remainder of W2 and all of W6, W8, W14, SW3, SW5, SW6, SW7 \& SW10 
Appendix 2: Dropping the Tallest/Largest Buildings from the Sample

\section{For Online Publication only}

Table A1: Robustness: Successively omitting largest (floorspace/site area) three TA buildings: Dep. var.: floorspace/site $\mathrm{m}^{2}$

\begin{tabular}{|c|c|c|c|c|}
\hline VARIABLES & $\begin{array}{c}(1) \\
\text { Floorspace/ } \\
\text { Site Area } \\
\text { Full Sample } \\
\end{array}$ & $\begin{array}{c}(2) \\
\text { Floorspace/ } \\
\text { Site Area } \\
\text { Omit Greatest }\end{array}$ & $\begin{array}{c}(3) \\
\text { Floorspace/ } \\
\text { Site Area } \\
\text { Omit } 2 \text { Greatest } \\
\end{array}$ & $\begin{array}{c}(4) \\
\text { Floorspace/ } \\
\text { Site Area } \\
\text { Omit } 3 \text { Greatest }\end{array}$ \\
\hline Modern TA outside HPA & $\begin{array}{c}5.422 * * * \\
(1.192)\end{array}$ & $\begin{array}{c}5.013 * * * \\
(1.156)\end{array}$ & $\begin{array}{c}4.494^{* * *} \\
(1.075)\end{array}$ & $\begin{array}{c}3.866 * * * \\
(0.914)\end{array}$ \\
\hline TA & $\begin{array}{l}-0.0116 \\
(0.210)\end{array}$ & $\begin{array}{l}-0.0124 \\
(0.210)\end{array}$ & $\begin{array}{c}-0.00328 \\
(0.209)\end{array}$ & $\begin{array}{c}0.00833 \\
(0.209)\end{array}$ \\
\hline Built in HPA & $\begin{array}{l}0.0758 \\
(0.157)\end{array}$ & $\begin{array}{l}0.0607 \\
(0.157)\end{array}$ & $\begin{array}{l}0.0819 \\
(0.156)\end{array}$ & $\begin{array}{l}0.0346 \\
(0.149)\end{array}$ \\
\hline Average Office Permission Refusal Rate & $\begin{array}{c}-7.448 * * * \\
(2.029)\end{array}$ & $\begin{array}{c}-7.397 * * * \\
(2.028)\end{array}$ & $\begin{array}{c}-7.272 * * * \\
(2.028)\end{array}$ & $\begin{array}{c}-7.027 * * * \\
(2.019)\end{array}$ \\
\hline Built 1950s & $\begin{array}{c}0.186 \\
(0.180)\end{array}$ & $\begin{array}{c}0.194 \\
(0.180)\end{array}$ & $\begin{array}{c}0.192 \\
(0.180)\end{array}$ & $\begin{array}{c}0.208 \\
(0.180)\end{array}$ \\
\hline Built 1960s & $\begin{array}{c}0.756^{* * * *} \\
(0.241)\end{array}$ & $\begin{array}{c}0.764 * * * \\
(0.241)\end{array}$ & $\begin{array}{c}0.760 * * * \\
(0.240)\end{array}$ & $\begin{array}{c}0.781^{* * * *} \\
(0.240)\end{array}$ \\
\hline Built 1970s & $\begin{array}{c}0.610 * * * \\
(0.233)\end{array}$ & $\begin{array}{c}0.620 * * * \\
(0.232)\end{array}$ & $\begin{array}{c}0.615 * * * \\
(0.231)\end{array}$ & $\begin{array}{c}0.642 * * * \\
(0.228)\end{array}$ \\
\hline Built 1980s & $\begin{array}{c}0.201 \\
(0.163)\end{array}$ & $\begin{array}{c}0.221 \\
(0.161)\end{array}$ & $\begin{array}{c}0.212 \\
(0.161)\end{array}$ & $\begin{array}{c}0.236 \\
(0.159)\end{array}$ \\
\hline Built 1990s & $\begin{array}{l}0.318^{*} \\
(0.185)\end{array}$ & $\begin{array}{l}0.354^{*} \\
(0.182)\end{array}$ & $\begin{array}{l}0.345^{*} \\
(0.182)\end{array}$ & $\begin{array}{c}0.375^{* *} \\
(0.181)\end{array}$ \\
\hline Built 2000s & $\begin{array}{c}1.362 * * * \\
(0.238)\end{array}$ & $\begin{array}{c}1.345^{* * *} \\
(0.236)\end{array}$ & $\begin{array}{c}1.352 * * * \\
(0.236)\end{array}$ & $\begin{array}{c}1.405^{* * *} \\
(0.230)\end{array}$ \\
\hline Built 2010s & $\begin{array}{c}1.556^{* * *} \\
(0.424)\end{array}$ & $\begin{array}{c}1.604^{* * *} \\
(0.422)\end{array}$ & $\begin{array}{c}1.493 * * * \\
(0.410)\end{array}$ & $\begin{array}{c}1.418^{* * *} \\
(0.403)\end{array}$ \\
\hline City of London & $\begin{array}{c}-1.025^{* * *} \\
(0.296)\end{array}$ & $\begin{array}{c}-1.018 * * * \\
(0.296)\end{array}$ & $\begin{array}{c}-0.998 * * * \\
(0.296)\end{array}$ & $\begin{array}{c}-0.961 * * * \\
(0.294)\end{array}$ \\
\hline Docklands & $\begin{array}{c}3.727 * * * \\
(0.827)\end{array}$ & $\begin{array}{c}3.453 * * * \\
(0.797)\end{array}$ & $\begin{array}{c}3.543 * * * \\
(0.795)\end{array}$ & $\begin{array}{c}3.621 * * * \\
(0.793)\end{array}$ \\
\hline Average Employment 600m & $\begin{array}{c}2.44 \mathrm{e}-05^{* * *} \\
(2.77 \mathrm{e}-06)\end{array}$ & $\begin{array}{c}2.45 \mathrm{e}-05^{* * *} \\
(2.77 \mathrm{e}-06)\end{array}$ & $\begin{array}{c}2.40 \mathrm{e}-05^{* * *} \\
(2.72 \mathrm{e}-06)\end{array}$ & $\begin{array}{c}2.42 \mathrm{e}-05^{* * *} \\
(2.71 \mathrm{e}-06)\end{array}$ \\
\hline Constant & $\begin{array}{c}3.749 * * * \\
(0.279)\end{array}$ & $\begin{array}{c}3.740 * * * \\
(0.279)\end{array}$ & $\begin{array}{c}3.743 * * * \\
(0.279)\end{array}$ & $\begin{array}{c}3.704 * * * \\
(0.277)\end{array}$ \\
\hline $\begin{array}{l}\text { Observations } \\
\text { R-squared }\end{array}$ & $\begin{array}{l}2,039 \\
0.269\end{array}$ & $\begin{array}{l}2,038 \\
0.253\end{array}$ & $\begin{array}{l}2,037 \\
0.242\end{array}$ & $\begin{array}{l}2,036 \\
0.236\end{array}$ \\
\hline
\end{tabular}

Robust standard errors in parentheses $\quad * * * \mathrm{p}<0.01, * * \mathrm{p}<0.05, * \mathrm{p}<0.1$

Table A1 successively removes the TA buildings with the greatest (Floorspace/Site Area) ratio in the sample. These are 8 Canada Square (26.02), 'The Cheesegrater' 122 Leadenhall (25.04), and 'The Shard' 32 London Bridge Street (23.62). 
Table A2: Robustness: Successively omitting tallest three TA buildings: Dep. var.: No. floors

\begin{tabular}{|c|c|c|c|c|}
\hline VARIABLES & $\begin{array}{c}\text { (1) } \\
\text { Floors } \\
\text { Full Sample }\end{array}$ & $\begin{array}{c}\text { (2) } \\
\text { Floors } \\
\text { Omit Tallest }\end{array}$ & $\begin{array}{c}(3) \\
\text { Floors } \\
\text { Omit } 2 \text { Talles } \\
\end{array}$ & $\begin{array}{c}\text { (4) } \\
\text { Floors } \\
\text { Omit } 3 \text { Tal } \\
\end{array}$ \\
\hline Modern TA outside HPA & $\begin{array}{c}14.29 * * * \\
(3.512)\end{array}$ & $\begin{array}{c}11.59 * * * \\
(2.390)\end{array}$ & $\begin{array}{c}10.30 * * * \\
(2.077)\end{array}$ & $\begin{array}{c}9.468 * * * \\
(1.987)\end{array}$ \\
\hline TA & $\begin{array}{c}0.952 * * * \\
(0.334)\end{array}$ & $\begin{array}{c}1.004^{* * *} \\
(0.331)\end{array}$ & $\begin{array}{c}1.027 * * * \\
(0.330)\end{array}$ & $\begin{array}{c}1.027 * * * \\
(0.330)\end{array}$ \\
\hline Built in HPA & $\begin{array}{c}-0.818^{* *} \\
(0.326)\end{array}$ & $\begin{array}{c}-1.037 * * * \\
(0.249)\end{array}$ & $\begin{array}{c}-0.989 * * * \\
(0.245)\end{array}$ & $\begin{array}{c}-1.019 * * * \\
(0.243)\end{array}$ \\
\hline Average Office Permission Refusal Rate & $\begin{array}{c}-10.42^{* * *} \\
(3.355)\end{array}$ & $\begin{array}{c}-9.330 * * * \\
(3.119)\end{array}$ & $\begin{array}{c}-9.005^{* * *} \\
(3.080)\end{array}$ & $\begin{array}{c}-8.888 * * * \\
(3.067)\end{array}$ \\
\hline Built 1950s & $\begin{array}{c}0.890 * * * \\
(0.285)\end{array}$ & $\begin{array}{c}0.964 * * * \\
(0.270)\end{array}$ & $\begin{array}{c}0.959 * * * \\
(0.266)\end{array}$ & $\begin{array}{c}0.975 * * * \\
(0.265)\end{array}$ \\
\hline Built 1960s & $\begin{array}{c}3.713 * * * \\
(0.676)\end{array}$ & $\begin{array}{c}3.806 * * * \\
(0.672)\end{array}$ & $\begin{array}{c}3.797 * * * \\
(0.673)\end{array}$ & $\begin{array}{c}3.815^{* * * *} \\
(0.673)\end{array}$ \\
\hline Built 1970s & $\begin{array}{c}2.127 * * * \\
(0.401)\end{array}$ & $\begin{array}{c}2.251^{* * * *} \\
(0.382)\end{array}$ & $\begin{array}{c}2.239 * * * \\
(0.382)\end{array}$ & $\begin{array}{c}2.260 * * * \\
(0.382)\end{array}$ \\
\hline Built 1980s & $\begin{array}{c}0.889 * * * \\
(0.267)\end{array}$ & $\begin{array}{c}0.998^{* * *} \\
(0.241)\end{array}$ & $\begin{array}{c}0.976 * * * \\
(0.238)\end{array}$ & $\begin{array}{c}1.014 * * * \\
(0.234)\end{array}$ \\
\hline Built 1990s & $\begin{array}{c}1.357 * * * \\
(0.317)\end{array}$ & $\begin{array}{c}1.490 * * * \\
(0.292)\end{array}$ & $\begin{array}{c}1.466 * * * \\
(0.293)\end{array}$ & $\begin{array}{c}1.536 * * * \\
(0.289)\end{array}$ \\
\hline Built 2000s & $\begin{array}{c}2.789 * * * \\
(0.430)\end{array}$ & $\begin{array}{c}3.035 * * * \\
(0.355)\end{array}$ & $\begin{array}{c}3.058 * * * \\
(0.355)\end{array}$ & $\begin{array}{c}3.030 * * * \\
(0.353)\end{array}$ \\
\hline Built 2010s & $\begin{array}{c}4.462 * * * \\
(0.801)\end{array}$ & $\begin{array}{c}4.131^{* * *} \\
(0.731)\end{array}$ & $\begin{array}{c}3.851^{* * *} \\
(0.679)\end{array}$ & $\begin{array}{c}3.931^{* * *} \\
(0.673)\end{array}$ \\
\hline City of London & $\begin{array}{c}-1.019 * * \\
(0.476)\end{array}$ & $\begin{array}{l}-0.855^{*} \\
(0.440)\end{array}$ & $\begin{array}{c}-0.804^{*} \\
(0.435)\end{array}$ & $\begin{array}{l}-0.791^{*} \\
(0.433)\end{array}$ \\
\hline Docklands & $\begin{array}{c}5.227 * * * \\
(1.756)\end{array}$ & $\begin{array}{c}5.613^{* * *} \\
(1.737)\end{array}$ & $\begin{array}{c}5.862 * * * \\
(1.735)\end{array}$ & $\begin{array}{c}5.355^{* * *} \\
(1.702)\end{array}$ \\
\hline Average Employment 600m & $\begin{array}{c}2.48 \mathrm{e}-05^{* * *} \\
(4.38 \mathrm{e}-06)\end{array}$ & $\begin{array}{c}2.58 \mathrm{e}-05 * * * \\
(4.26 \mathrm{e}-06)\end{array}$ & $\begin{array}{c}2.46 \mathrm{e}-05^{* * *} \\
(4.09 \mathrm{e}-06)\end{array}$ & $\begin{array}{c}2.48 \mathrm{e}-05^{* * *} \\
(4.08 \mathrm{e}-06)\end{array}$ \\
\hline Constant & $\begin{array}{c}6.639 * * * \\
(0.448)\end{array}$ & $\begin{array}{c}6.461^{* * *} \\
(0.406)\end{array}$ & $\begin{array}{c}6.464 * * * \\
(0.403)\end{array}$ & $\begin{array}{c}6.443 * * * \\
(0.402)\end{array}$ \\
\hline Observations & 2,039 & 2,038 & 2,037 & 2,036 \\
\hline R-squared & 0.361 & 0.365 & 0.350 & 0.331 \\
\hline
\end{tabular}

Robust standard errors in parentheses $\quad * * * \mathrm{p}<0.01,{ }^{* *} \mathrm{p}<0.05, * \mathrm{p}<0.1$

Table A2 successively removes the TA buildings from the sample in order of most above ground floors. These are 'The Shard' 32 London Bridge Street (87F), 'The Cheesegrater' 122 Leadenhall Street (48F), and 25 Canada Square (45F). 


\section{For Online Publication only}

Appendix 3: Causal Interpretation of Relationship between TA Design and Additional Stories?

As discussed in Section 5 of the paper we identified two possible objections to the causal interpretation we have put onto the strong relationship between whether a building is in a nonHPA and designed by a modern TA, on the one hand, and its additional height and resulting increased value of the site all else controlled for, on the other. The first of these objections is that companies wishing to make a landmark statement may tend to commission both taller buildings and TAs to be their designers. The second is that designing tall buildings is particularly demanding of architectural skill so tall buildings are more likely to be designed by famous - or trophy - architects.

The crux of the first objection to our interpretation of causation is that bespoke developments must both cause (i) buildings to be tall and (ii) TAs to be chosen as their architect. If either of these is false, then the bespoke status of developments cannot be an explanation of why TA buildings are taller than those of 'normal' architects.

To address the first of these relationships, we take TA status as given 13 and determine whether bespoke status can influence building height. Table A3 below shows that there have been 59 modern office buildings built by TAs in London. Of these 59, 20 (or 34 percent), were commissioned to be built by a firm specifically for their own use. Following our earlier analyses, Table A4 shows a series of hierarchical regressions on the height of modern TA buildings depending on bespoke status and a number of controls. Under none of the specifications is the bespoke variable a statistically significant determinant of building height. Robust standard errors are shown because heteroskedasticity is identified in the data with a White test; homoskedastic standard errors yield the same result.

\section{Tables A3 \& A4 about here}

To address the second necessary assumption that bespoke developments preferentially choose TA designers, we now take tall building status as given 14 and determine whether bespoke status 


\section{"Trophy Architects" and design as rent-seeking: \\ Quantifying deadweight losses in a tightly regulated office market}

influences the likelihood of choosing a TA. Table A5 shows the 47 office buildings in London that have ever been built above 20 floors, and of these 20, or 43 percent, were bespoke. Now examining TAs, 13 of these 47 buildings were designed by TAs, and of these TA buildings 6 , or 46 percent, were also bespoke. A comparison of means test does not reject the null hypothesis that among London's tallest offices the probability that a given (TA or non-TA) building will be bespoke is identical to the probability that a TA building specifically will be bespoke $(\mathrm{p}=0.80)$. Therefore bespoke developments do not appear to be either taller (necessary assumption 1) or to preferentially choose TA designers (necessary assumption 2). Either of these findings alone would be sufficient to invalidate the inference that bespoke status accounts for our observed relationship between TAs and building height, but together this conclusion is stronger still.

\section{Table A5 about here}

As a way of addressing the second potential criticism of our causal interpretation - that only TAs have the requisite skills to design tall buildings, Table A6 provides data on tall buildings from a selection of cities around the world. These cities are selected because they have comparatively flexible restrictions on building tall. They are: Chicago, Houston, Brussels, Benidorm (Spain), and Sao Paulo. Chicago and Houston are at the least restrictive end of the US spectrum of restrictiveness with respect to commercial buildings at least. Brussels was the office centre in Western Europe identified by Cheshire and Hilber (2008) as having the lowest estimated value of Regulatory Tax. Benidorm, especially when it was developed as a resort town during the 1970s and 1980s, had both lax restriction and lax enforcement, and while Sao Paolo does have significant restrictions on very tall buildings it is quite unrestrictive with respect to buildings up to 100 meters. The sample of buildings in these cities consisted of those buildings above 100m: corresponding to roughly 25-floors.

\section{Table A6 about here}

We can see that only a small fraction (2.3 percent) of the tallest buildings in these five international cities was designed by a TA, and that this fraction is an order of magnitude lower than in London. There are also no TA buildings at all in Brussels or Benidorm - both cities with a far higher incidence of tall buildings per capita than London. A comparison of means 
test rejects with high confidence the probability that there is no difference between the incidence of tall TA buildings in London and the other cities $(\mathrm{p}<0.0001)$. This result contradicts the idea that only TAs have the skills to build tall. It is also suggestive that there is a unique process at work in London which associates tall buildings with TAs: we argue that this process is rent-seeking in the face of a highly restrictive planning regime; not bespoke status or TAs' technical skill.

\section{Table A7 about here}


Table A3: Are bespoke buildings taller? Population of Modern TA office buildings in London (n=59)

\begin{tabular}{|c|c|c|c|c|c|c|c|}
\hline Building Name & Address & TA & Award & Floors & $\begin{array}{c}\text { Year } \\
\text { Approved }\end{array}$ & Borough & Bespoke \\
\hline 'The Shard' & $\begin{array}{l}32 \text { London Bridge } \\
\text { Street }\end{array}$ & Renzo Piano & $\begin{array}{l}\text { RIBA Gold 1989, } \\
\text { AIA Gold 2008, } \\
\text { Pritzker } 1998\end{array}$ & 87 & 2003 & Southwark & $\mathrm{NO}$ \\
\hline \multirow[t]{6}{*}{ 'The Cheesegrater' } & 122 Leadenhall & Richard Rogers & $\begin{array}{l}\text { RIBA Gold 1985, } \\
\text { Pritzker } 2007\end{array}$ & 50 & 2004 & City of London & NO \\
\hline & 25 Canada Square & Cesar Pelli & AIA Gold 1995 & 45 & 1998 & Tower Hamlets & YES \\
\hline & 8 Canada Square & Norman Foster & $\begin{array}{l}\text { RIBA Gold 1983, } \\
\text { AIA Gold 1994, } \\
\text { Pritzker } 1999\end{array}$ & 45 & 1997 & Tower Hamlets & YES \\
\hline & 30 St Mary Axe & Norman Foster & $\begin{array}{l}\text { RIBA Gold 1983, } \\
\text { AIA Gold 1994, } \\
\text { Pritzker } 1999\end{array}$ & 40 & 1997 & City of London & YES \\
\hline & 25 Bank Street & Cesar Pelli & AIA Gold 1995 & 33 & 2001 & Tower Hamlets & NO \\
\hline & 40 Bank Street & Cesar Pelli & AIA Gold 1995 & 33 & 2001 & Tower Hamlets & NO \\
\hline Willis Building & 51 Lime Street & Norman Foster & $\begin{array}{l}\text { RIBA Gold 1983, } \\
\text { AIA Gold 1994, } \\
\text { Pritzker } 1999\end{array}$ & 26 & 2002 & City of London & YES \\
\hline \multirow[t]{3}{*}{ Shell Centre } & 2 York Road & Howard Robertson & RIBA Gold 1949 & 26 & 1957 & Lambeth & YES \\
\hline & 33 Canada Square & Norman Foster & $\begin{array}{l}\text { RIBA Gold 1983, } \\
\text { AIA Gold 1994, } \\
\text { Pritzker } 1999\end{array}$ & 24 & 1996 & Tower Hamlets & YES \\
\hline & 1 Cabot Square & Ieoh Ming Pei & $\begin{array}{l}\text { RIBA Gold 2010, } \\
\text { AIA Gold 1979, } \\
\text { Pritzker } 1983\end{array}$ & 21 & 1988 & Tower Hamlets & NO \\
\hline \multirow[t]{2}{*}{ Bastion House } & 140 London Wall & $\begin{array}{l}\text { Phillip Powell \& } \\
\text { Hidalgo Moya }\end{array}$ & RIBA Gold 1974 & 21 & 1974 & City of London & $\mathrm{NO}$ \\
\hline & $\begin{array}{l}12 \text { Endeavour } \\
\text { Square }\end{array}$ & Richard Rogers & $\begin{array}{l}\text { RIBA Gold 1985, } \\
\text { Pritzker } 2007\end{array}$ & 20 & 2015 & Newham & NO \\
\hline Moor House & 120 London Wall & Norman Foster & $\begin{array}{l}\text { RIBA Gold 1983, } \\
\text { AIA Gold 1994, } \\
\text { Pritzker } 1999\end{array}$ & 19 & 1998 & City of London & $\mathrm{NO}$ \\
\hline \multirow[t]{2}{*}{ The Place } & $\begin{array}{l}25 \text { London Bridge } \\
\text { Street }\end{array}$ & Renzo Piano & $\begin{array}{l}\text { RIBA Gold 1989, } \\
\text { AIA Gold 2008, } \\
\text { Pritzker } 1998\end{array}$ & 18 & 2007 & Southwark & NO \\
\hline & 88 Wood Street & Richard Rogers & $\begin{array}{l}\text { RIBA Gold 1985, } \\
\text { Pritzker } 2007\end{array}$ & 18 & 1995 & City of London & NO \\
\hline
\end{tabular}


"Trophy Architects" and design as rent-seeking:

Quantifying deadweight losses in a tightly regulated office market

\begin{tabular}{|c|c|c|c|c|c|c|c|}
\hline Principal Place & 115 Worship Street & Norman Foster & $\begin{array}{l}\text { RIBA Gold 1983, } \\
\text { AIA Gold 1994, } \\
\text { Pritzker } 1999\end{array}$ & 17 & 2017 & Hackney & NO \\
\hline New Court & St Swithin’s Lane & Rem Koolhaas & $\begin{array}{l}\text { RIBA Gold 2004, } \\
\text { Pritzker } 2000\end{array}$ & 16 & 2006 & City of London & YES \\
\hline Central St Giles & $\begin{array}{l}\text { 1-13 St Giles High } \\
\text { Street }\end{array}$ & Renzo Piano & $\begin{array}{l}\text { RIBA Gold 1989, } \\
\text { AIA Gold 2008, } \\
\text { Pritzker } 1998 \\
\end{array}$ & 15 & 2005 & Camden & NO \\
\hline $\begin{array}{l}\text { New Lloyd's } \\
\text { Register of Shipping }\end{array}$ & 71 Fenchurch Street & Richard Rogers & $\begin{array}{l}\text { RIBA Gold 1985, } \\
\text { Pritzker } 2007\end{array}$ & 14 & 1996 & City of London & YES \\
\hline \multirow[t]{4}{*}{ Fountain House } & $\begin{array}{l}130 \text { Fenchurch } \\
\text { Street }\end{array}$ & Howard Robertson & RIBA Gold 1949 & 14 & 1956 & City of London & NO \\
\hline & 5 Endeavour Square & Richard Rogers & $\begin{array}{l}\text { RIBA Gold 1985, } \\
\text { Pritzker } 2007\end{array}$ & 13 & 2015 & Newham & NO \\
\hline & 10 Bishop’s Square & Norman Foster & $\begin{array}{l}\text { RIBA Gold 1983, } \\
\text { AIA Gold 1994, } \\
\text { Pritzker } 1999\end{array}$ & 13 & 2001 & Tower Hamlets & NO \\
\hline & 1 London Wall & Norman Foster & $\begin{array}{l}\text { RIBA Gold 1983, } \\
\text { AIA Gold 1994, } \\
\text { Pritzker } 1999\end{array}$ & 13 & 2000 & City of London & NO \\
\hline Building 7 & $\begin{array}{l}\text { Chiswick Business } \\
\text { Park }\end{array}$ & Richard Rogers & $\begin{array}{l}\text { RIBA Gold 1985, } \\
\text { Pritzker } 2007\end{array}$ & 12 & 2014 & Hounslow & NO \\
\hline \multirow[t]{2}{*}{$\begin{array}{l}\text { Paddington } \\
\text { Waterside }\end{array}$} & $\begin{array}{l}35 \text { North Wharf } \\
\text { Road }\end{array}$ & Richard Rogers & $\begin{array}{l}\text { RIBA Gold 1985, } \\
\text { Pritzker } 2007\end{array}$ & 12 & 2001 & Westminster & NO \\
\hline & $\begin{array}{l}100 \text { Liverpool } \\
\text { Street }\end{array}$ & $\begin{array}{l}\text { Michael \& Patricia } \\
\text { Hopkins }\end{array}$ & RIBA Gold 1994 & 11 & 2015 & City of London & NO \\
\hline \multirow[t]{2}{*}{ Roman Wall House } & 1-2 Crutched Friars & $\begin{array}{l}\text { Michael \& Patricia } \\
\text { Hopkins }\end{array}$ & RIBA Gold 1994 & 11 & 2014 & City of London & NO \\
\hline & 100 Wood Street & Norman Foster & $\begin{array}{l}\text { RIBA Gold 1983, } \\
\text { AIA Gold 1994, } \\
\text { Pritzker } 1999\end{array}$ & 11 & 1997 & City of London & NO \\
\hline \multirow[t]{3}{*}{ Langbourne House } & 10 Fenchurch Street & Denys Lasdun & RIBA Gold 1977 & 11 & 1982 & City of London & NO \\
\hline & $\begin{array}{l}1 \text { More London } \\
\text { Place }\end{array}$ & Norman Foster & $\begin{array}{l}\text { RIBA Gold 1983, } \\
\text { AIA Gold 1994, } \\
\text { Pritzker } 1999\end{array}$ & 10 & 2000 & Southwark & YES \\
\hline & $\begin{array}{l}3 \text { More London } \\
\text { Place }\end{array}$ & Norman Foster & $\begin{array}{l}\text { RIBA Gold 1983, } \\
\text { AIA Gold 1994, } \\
\text { Pritzker } 1999\end{array}$ & 10 & 2000 & Southwark & NO \\
\hline
\end{tabular}


"Trophy Architects" and design as rent-seeking:

Quantifying deadweight losses in a tightly regulated office market

\begin{tabular}{|c|c|c|c|c|c|c|c|}
\hline Gibbs Building & 215 Euston Road & $\begin{array}{l}\text { Michael \& Patricia } \\
\text { Hopkins }\end{array}$ & RIBA Gold 1994 & 10 & 2000 & Camden & YES \\
\hline City Hall & $\begin{array}{l}110 \text { The Queen’s } \\
\text { Walk }\end{array}$ & Norman Foster & $\begin{array}{l}\text { RIBA Gold 1983, } \\
\text { AIA Gold 1994, } \\
\text { Pritzker } 1999\end{array}$ & 10 & 1998 & Southwark & YES \\
\hline Reuter's Building & 1 Paul Julius & Richard Rogers & $\begin{array}{l}\text { RIBA Gold 1985, } \\
\text { Pritzker } 2007\end{array}$ & 10 & 1992 & Tower Hamlets & YES \\
\hline The Ark & 201 Talgarth Road & Ralph Erskine & RIBA Gold 1987 & 10 & 1989 & Hammersmith & NO \\
\hline ITN Building & $\begin{array}{l}200 \text { Gray’s Inn } \\
\text { Road }\end{array}$ & Norman Foster & $\begin{array}{l}\text { RIBA Gold 1983, } \\
\text { AIA Gold 1994, } \\
\text { Pritzker } 1999\end{array}$ & 10 & 1989 & Camden & YES \\
\hline $\begin{array}{l}\text { Board of Trade } \\
\text { Building }\end{array}$ & Whitehall & $\begin{array}{l}\text { Emmanuel Vincent } \\
\text { Harries }\end{array}$ & RIBA Gold 1951 & 10 & 1957 & Westminster & YES \\
\hline Holborn Place & 33 Holborn Circus & Norman Foster & $\begin{array}{l}\text { RIBA Gold 1983, } \\
\text { AIA Gold 1994, } \\
\text { Pritzker } 1999\end{array}$ & 9 & 1995 & City of London & NO \\
\hline Milton Gate & 1 Moor Lane & Denys Lasdun & RIBA Gold 1977 & 9 & 1986 & City of London & NO \\
\hline $\begin{array}{l}\text { Bloomberg Place } \\
\text { Building } 1\end{array}$ & 50 Cannon Street & Norman Foster & $\begin{array}{l}\text { RIBA Gold 1983, } \\
\text { AIA Gold 1994, } \\
\text { Pritzker } 1999\end{array}$ & 8 & 2012 & City of London & YES \\
\hline $\begin{array}{l}\text { Bloomberg Place } \\
\text { Building } 2\end{array}$ & 50 Cannon Street & Norman Foster & $\begin{array}{l}\text { RIBA Gold 1983, } \\
\text { AIA Gold 1994, } \\
\text { Pritzker } 1999\end{array}$ & 8 & 2012 & City of London & YES \\
\hline The Walbrook & 25 Walbrook & Norman Foster & $\begin{array}{l}\text { RIBA Gold 1983, } \\
\text { AIA Gold 1994, } \\
\text { Pritzker } 1999 \\
\end{array}$ & 8 & 2007 & City of London & $\mathrm{NO}$ \\
\hline \multirow[t]{4}{*}{ One New Change } & 9-36 Cheapside & Jean Nouvel & $\begin{array}{l}\text { RIBA Gold 2001, } \\
\text { Pritzker } 2008\end{array}$ & 8 & 2005 & City of London & $\mathrm{NO}$ \\
\hline & $\begin{array}{l}2 \text { More London } \\
\text { Place }\end{array}$ & Norman Foster & $\begin{array}{l}\text { RIBA Gold 1983, } \\
\text { AIA Gold 1994, } \\
\text { Pritzker } 1999\end{array}$ & 8 & 2000 & Southwark & YES \\
\hline & $\begin{array}{l}4 \text { More London } \\
\text { Place }\end{array}$ & Norman Foster & $\begin{array}{l}\text { RIBA Gold 1983, } \\
\text { AIA Gold 1994, } \\
\text { Pritzker } 1999\end{array}$ & 8 & 2000 & Southwark & NO \\
\hline & $\begin{array}{l}6 \text { More London } \\
\text { Place }\end{array}$ & Norman Foster & $\begin{array}{l}\text { RIBA Gold 1983, } \\
\text { AIA Gold 1994, } \\
\text { Pritzker } 1999\end{array}$ & 8 & 2000 & Southwark & NO \\
\hline
\end{tabular}


"Trophy Architects" and design as rent-seeking:

Quantifying deadweight losses in a tightly regulated office market

\begin{tabular}{|c|c|c|c|c|c|c|c|}
\hline & $\begin{array}{l}7 \text { More London } \\
\text { Place }\end{array}$ & Norman Foster & $\begin{array}{l}\text { RIBA Gold 1983, } \\
\text { AIA Gold 1994, } \\
\text { Pritzker } 1999\end{array}$ & 8 & 2000 & Southwark & YES \\
\hline \multirow[t]{3}{*}{ Tower Bridge House } & $\begin{array}{l}\text { St Katharine’s } \\
\text { Dock }\end{array}$ & Richard Rogers & $\begin{array}{l}\text { RIBA Gold 1985, } \\
\text { Pritzker } 2007\end{array}$ & 8 & 1999 & Tower Hamlets & $\mathrm{NO}$ \\
\hline & 50 Finsbury Square & Norman Foster & $\begin{array}{l}\text { RIBA Gold 1983, } \\
\text { AIA Gold 1994, } \\
\text { Pritzker } 1999\end{array}$ & 8 & 1998 & Islington & $\mathrm{NO}$ \\
\hline & 10 Gresham Street & Norman Foster & $\begin{array}{l}\text { RIBA Gold 1983, } \\
\text { AIA Gold 1994, } \\
\text { Pritzker } 1999\end{array}$ & 8 & 1997 & City of London & $\mathrm{NO}$ \\
\hline Tower Place West & Tower Hill & Norman Foster & $\begin{array}{l}\text { RIBA Gold 1983, } \\
\text { AIA Gold 1994, } \\
\text { Pritzker } 1999\end{array}$ & 7 & 1998 & City of London & $\mathrm{NO}$ \\
\hline Broadwick House & $\begin{array}{l}\text { 15-17 Broadwick } \\
\text { Road }\end{array}$ & Richard Rogers & $\begin{array}{l}\text { RIBA Gold 1985, } \\
\text { Pritzker } 2007\end{array}$ & 7 & 1998 & Westminster & $\mathrm{NO}$ \\
\hline \multirow[t]{2}{*}{ Stirling Square } & $\begin{array}{l}\text { 1-5 Carlton } \\
\text { Gardens }\end{array}$ & James Stirling & Pritzker 1981 & 7 & 1988 & Westminster & NO \\
\hline & 1 Poultry & James Stirling & Pritzker 1981 & 7 & 1986 & City of London & NO \\
\hline $\begin{array}{l}\text { Neo Bankside } \\
\text { Pavillion E }\end{array}$ & $\begin{array}{l}118 \text { Southwark } \\
\text { Street }\end{array}$ & Richard Rogers & $\begin{array}{l}\text { RIBA Gold 1985, } \\
\text { Pritzker } 2007\end{array}$ & 6 & 2006 & Southwark & $\mathrm{NO}$ \\
\hline $\begin{array}{l}\text { Channel } 4 \\
\text { Headquarters } \\
\end{array}$ & $\begin{array}{l}124 \text { Horseferry } \\
\text { Road }\end{array}$ & Richard Rogers & $\begin{array}{l}\text { RIBA Gold 1985, } \\
\text { Pritzker } 2007\end{array}$ & 5 & 1991 & Westminster & YES \\
\hline \multirow[t]{2}{*}{$\begin{array}{l}\text { Francis Taylor } \\
\text { Building } \\
\end{array}$} & Inner Temple & Edward Maufe & RIBA Gold 1944 & 5 & 1956 & City of London & YES \\
\hline & $\begin{array}{l}16 \text { Winchester } \\
\text { Walk }\end{array}$ & Edward Cullinan & RIBA Gold 2008 & 4 & 2016 & Southwark & $\mathrm{NO}$ \\
\hline
\end{tabular}


"Trophy Architects" and design as rent-seeking:

Quantifying deadweight losses in a tightly regulated office market

Table A4: Bespoke status on Modern TA building height

\begin{tabular}{|c|c|c|c|c|c|}
\hline VARIABLES & $\begin{array}{c}(1) \\
\text { Floors }\end{array}$ & $\begin{array}{c}(2) \\
\text { Floors } \\
\end{array}$ & $\begin{array}{c}(3) \\
\text { Floors } \\
\end{array}$ & $\begin{array}{c}(4) \\
\text { Floors }\end{array}$ & $\begin{array}{c}(5) \\
\text { Floors }\end{array}$ \\
\hline Bespoke & $\begin{array}{c}1.527 \\
(3.776)\end{array}$ & $\begin{array}{c}1.817 \\
(3.746)\end{array}$ & $\begin{array}{l}-0.335 \\
(3.387)\end{array}$ & $\begin{array}{c}0.182 \\
(3.368)\end{array}$ & $\begin{array}{c}-3.047 \\
(5.662)\end{array}$ \\
\hline Built in HPA & $\begin{array}{c}-8.175^{* *} \\
(3.873)\end{array}$ & $\begin{array}{c}-9.837 * * \\
(4.129)\end{array}$ & $\begin{array}{l}-6.102 \\
(3.816)\end{array}$ & $\begin{array}{l}-6.427 \\
(3.900)\end{array}$ & $\begin{array}{c}-4.172 \\
(5.877)\end{array}$ \\
\hline (Bespoke) $\times($ Built Outside HPA) & & & & & $\begin{array}{c}7.250 \\
(9.577)\end{array}$ \\
\hline Average Office Permission Refusal Rate & $\begin{array}{l}-3.119 \\
(23.42)\end{array}$ & $\begin{array}{l}-8.086 \\
(24.46)\end{array}$ & $\begin{array}{l}-36.41 \\
(79.89)\end{array}$ & $\begin{array}{l}-23.74 \\
(88.83)\end{array}$ & $\begin{array}{l}-12.79 \\
(81.68)\end{array}$ \\
\hline City of London & & & $\begin{array}{c}-3.974 \\
(13.28)\end{array}$ & $\begin{array}{c}-9.263 \\
(12.09)\end{array}$ & $\begin{array}{c}-8.200 \\
(11.40)\end{array}$ \\
\hline Docklands & & & $\begin{array}{c}17.59 * * \\
(6.598)\end{array}$ & $\begin{array}{c}16.79 * * \\
(6.685)\end{array}$ & $\begin{array}{c}16.01^{* *} \\
(6.907)\end{array}$ \\
\hline Average Employment 600m & & & & 0.000117 & 0.000111 \\
\hline Decade Permission Granted & NO & YES & YES & $\begin{array}{c}\text { YES } \\
(0.000109)\end{array}$ & $\begin{array}{c}\text { YES } \\
(0.000118)\end{array}$ \\
\hline Constant & $\begin{array}{c}21.00 * * * \\
(3.346)\end{array}$ & $\begin{array}{l}12.39 * * \\
(4.857)\end{array}$ & $\begin{array}{c}16.37 \\
(13.42)\end{array}$ & $\begin{array}{c}12.54 \\
(15.61)\end{array}$ & $\begin{array}{c}10.75 \\
(14.62)\end{array}$ \\
\hline Observations & 59 & 59 & 59 & 59 & 59 \\
\hline R-squared & 0.077 & 0.133 & 0.248 & 0.263 & 0.273 \\
\hline
\end{tabular}

Robust standard errors in parentheses $\quad * * * \mathrm{p}<0.01,{ }^{* *} \mathrm{p}<0.05, * \mathrm{p}<0.1$ 
Table A5: Are bespoke buildings designed by TAs? Population of London office buildings $>$ 20-floors (n=47)

\begin{tabular}{|c|c|c|c|c|c|c|c|c|c|}
\hline Building Name & Address & Architect & TA & Bespoke & Floors & Height & $\begin{array}{l}\text { Year } \\
\text { Built }\end{array}$ & Local Authority & Demolished \\
\hline 'The Shard' & 32 London Bridge Street & Renzo Piano & YES & $\mathrm{NO}$ & 87 & $310 \mathrm{~m}$ & 2012 & Southwark & - \\
\hline One Canada Square & 1 Canada Square & Cesar Pelli & $\mathrm{NO}$ & $\mathrm{NO}$ & 50 & $235 \mathrm{~m}$ & 1991 & Tower Hamlets & - \\
\hline 'The Cheesegrater' & 122 Leadenhall Street & Richard Rogers & YES & $\mathrm{NO}$ & 48 & $225 \mathrm{~m}$ & 2014 & City of London & - \\
\hline Tower 42 & 25 Old Broad Street & Richard Seifert & $\mathrm{NO}$ & YES & 47 & $183 m$ & 1980 & City of London & - \\
\hline Heron Tower & 110 Bishopsgate & Kohn Pedersen Fox & $\mathrm{NO}$ & $\mathrm{NO}$ & 46 & $203 m$ & 2011 & City of London & - \\
\hline HSBC Tower & 8 Canada Square & Norman Foster & YES & YES & 45 & $200 \mathrm{~m}$ & 2002 & Tower Hamlets & - \\
\hline- & 25 Canada Square & Cesar Pelli & YES & YES & 45 & $220 \mathrm{~m}$ & 2002 & Tower Hamlets & - \\
\hline 'The Gherkin’ & 30 St Mary Axe & Norman Foster & YES & YES & 40 & $180 \mathrm{~m}$ & 2003 & City of London & - \\
\hline 'The Scalpel' & 52-54 Lime Street & Kohn Pedersen Fox & $\mathrm{NO}$ & YES & 39 & $192 \mathrm{~m}$ & 2018 & City of London & - \\
\hline 'The Walkie-Talkie' & 20 Fenchurch Street & Rafael Vinoli & $\mathrm{NO}$ & $\mathrm{NO}$ & 36 & $160 \mathrm{~m}$ & 2014 & City of London & - \\
\hline Euston Tower & 286 Euston Road & $\begin{array}{l}\text { Sidney Kaye, Eric } \\
\text { Firmin \& Partners }\end{array}$ & $\mathrm{NO}$ & $\mathrm{NO}$ & $36 \dagger$ & $124 \mathrm{~m}$ & 1970 & Camden & - \\
\hline Britannic House & 1 Ropemaker Street & $\begin{array}{l}\text { F. Milton Cashmore } \\
\text { \& Niall D. Nelson }\end{array}$ & $\mathrm{NO}$ & YES & $35 \ddagger$ & $122 \mathrm{~m}$ & 1967 & City of London & - \\
\hline Broadgate Tower & 201 Bishopsgate & $\begin{array}{l}\text { Skidmore, Owings, } \\
\text { and Merrill }\end{array}$ & NO & $\mathrm{NO}$ & 33 & $164 \mathrm{~m}$ & 2009 & City of London & - \\
\hline- & 25 Bank Street & Cesar Pelli & YES & $\mathrm{NO}$ & 33 & $153 \mathrm{~m}$ & 2003 & Tower Hamlets & - \\
\hline- & 40 Bank Street & Cesar Pelli & YES & $\mathrm{NO}$ & 33 & $153 \mathrm{~m}$ & 2003 & Tower Hamlets & - \\
\hline Centre Point & 103 New Oxford Street & Richard Seifert & $\mathrm{NO}$ & NO & 33† & $121 \mathrm{~m}$ & 1965 & Camden & - \\
\hline One Churchill Place & 1 Churchill Place & HOK International & $\mathrm{NO}$ & YES & 32 & $156 \mathrm{~m}$ & 2004 & Tower Hamlets & - \\
\hline Millbank Tower & 21-24 Millbank & $\begin{array}{l}\text { Ronald Ward \& } \\
\text { Partners }\end{array}$ & NO & YES & 32 & $118 \mathrm{~m}$ & 1961 & Westminster & - \\
\hline- & 10 Upper Bank Street & Kohn Pedersen Fox & NO & YES & 31 & $151 \mathrm{~m}$ & 2003 & Tower Hamlets & - \\
\hline King’s Reach Tower & Stamford Street & Richard Seifert & $\mathrm{NO}$ & NO & $29 \ddagger$ & $111 \mathrm{~m}$ & 1978 & Southwark & - \\
\hline
\end{tabular}


"Trophy Architects" and design as rent-seeking:

Quantifying deadweight losses in a tightly regulated office market

\begin{tabular}{|c|c|c|c|c|c|c|c|c|c|}
\hline Empress State Building & Empress Approach & $\begin{array}{l}\text { Stone, Toms \& } \\
\text { Partners }\end{array}$ & NO & $\mathrm{NO}$ & $28 \ddagger$ & $100 \mathrm{~m}$ & 1961 & Hammersmith & - \\
\hline Portland House & Bressenden Place & $\begin{array}{l}\text { Howard Fairbairn \& } \\
\text { Partners }\end{array}$ & NO & NO & 28 & $102 \mathrm{~m}$ & 1963 & Westminster & - \\
\hline The Willis Building & 51 Lime Street & Norman Foster & YES & YES & 28 & $125 \mathrm{~m}$ & 2007 & City of London & - \\
\hline Drapers Gardens & 12 Throgmorton Street & Richard Seifert & NO & YES & 28 & $99 m$ & 1967 & City of London & 2007 \\
\hline $\begin{array}{l}\text { Commercial Union } \\
\text { Tower }\end{array}$ & 1 Undershaft & $\begin{array}{l}\text { Gollins, Melvin, } \\
\text { Ward }\end{array}$ & NO & YES & 26 & $118 \mathrm{~m}$ & 1969 & City of London & - \\
\hline Shell Centre & 2 York Road & Howard Robertson & YES & YES & 26 & $107 \mathrm{~m}$ & 1962 & Lambeth & - \\
\hline Stock Exchange Tower & 125 Old Broad Street & $\begin{array}{l}\text { F. Milton Cashmore } \\
\text { \& Partners }\end{array}$ & NO & YES & $26 \ddagger$ & $99 m$ & 1969 & City of London & - \\
\hline Limebank House & 168 Fenchurch Street & Richard Seifert & NO & YES & 26 & $93 \mathrm{~m}$ & 1969 & City of London & 1998 \\
\hline $\begin{array}{l}\text { Kleinwort Benson } \\
\text { Building }\end{array}$ & 20 Fenchurch Street & William H. Rogers & NO & YES & 25 & $91 \mathrm{~m}$ & 1968 & City of London & 2008 \\
\hline $\begin{array}{l}\text { New London Bridge } \\
\text { House }\end{array}$ & 25 London Bridge Street & Richard Seifert & NO & NO & 25 & $94 \mathrm{~m}$ & 1967 & Southwark & 2010 \\
\hline- & 99 Bishopsgate & Richard Seifert & NO & NO & 25 & $104 \mathrm{~m}$ & 1976 & City of London & - \\
\hline The London Studios & 58-72 Upper Ground & $\begin{array}{l}\text { Elsom Pack \& } \\
\text { Roberts }\end{array}$ & NO & YES & 25 & $82 \mathrm{~m}$ & 1973 & Southwark & - \\
\hline Southwark Towers & 32 London Bridge Street & T.P. Bennett \& Son & NO & NO & 25 & $100 \mathrm{~m}$ & 1976 & Southwark & 2009 \\
\hline- & 33 Canada Square & Norman Foster & YES & YES & 24 & $105 \mathrm{~m}$ & 1999 & Tower Hamlets & - \\
\hline 'The Can of Ham' & 60 St Mary Axe & Foggo Associates & NO & NO & 23 & $91 \mathrm{~m}$ & 2018 & City of London & - \\
\hline Ropemaker Place & 25 Ropemaker Street & Arup Associates & NO & NO & 23 & $96 \mathrm{~m}$ & 2006 & Islington & - \\
\hline Marble Arch Tower & 55 Bryanston Street & T.P. Bennett \& Son & NO & NO & 23 & $82 \mathrm{~m}$ & 1966 & Westminster & - \\
\hline Market Towers & 1 Nine Elms Lane & GMW Architects & NO & YES & 23 & $75 \mathrm{~m}$ & 1975 & Lambeth & - \\
\hline- & 6-8 Bishopsgate & GMW Architects & NO & YES & 23 & $88 \mathrm{~m}$ & 1981 & City of London & - \\
\hline $\begin{array}{l}\text { IQL S9 International } \\
\text { Quarter }\end{array}$ & 12 Endeavour Square & Richard Rogers & YES & NO & 23 & $92 \mathrm{~m}$ & 2018 & Newham & - \\
\hline
\end{tabular}


"Trophy Architects" and design as rent-seeking:

Quantifying deadweight losses in a tightly regulated office market

\begin{tabular}{|c|c|c|c|c|c|c|c|c|c|}
\hline Westminster City Hall & 64 Victoria Street & $\begin{array}{l}\text { Burnet, Tait and } \\
\text { Partners }\end{array}$ & NO & NO & 22 & $76 \mathrm{~m}$ & 1966 & Westminster & - \\
\hline Angel Court & 1 Angel Court & $\begin{array}{l}\text { Fitzroy Robinson } \\
\text { and Partners }\end{array}$ & $\mathrm{NO}$ & $\mathrm{NO}$ & 21 & $94 m$ & 1980 & City of London & - \\
\hline - & 200 Aldersgate Street & $\begin{array}{l}\text { Fitzroy Robinson } \\
\text { and Partners }\end{array}$ & NO & $\mathrm{NO}$ & 21 & $91 \mathrm{~m}$ & 1992 & City of London & - \\
\hline One Cabot Square & 1 Cabot Square & $\begin{array}{l}\text { Pei, Cobb, Freed \& } \\
\text { Partners }\end{array}$ & YES & $\mathrm{NO}$ & 21 & $89 m$ & 1991 & Tower Hamlets & - \\
\hline Bastion House & 140 London Wall & $\begin{array}{l}\text { Phillip Powell \& } \\
\text { Hidalgo Moya }\end{array}$ & YES & $\mathrm{NO}$ & 21 & $69 \mathrm{~m}$ & 1976 & City of London & - \\
\hline Century House & $\begin{array}{l}100 \text { Westminster Bridge } \\
\text { Road }\end{array}$ & Devereux Architects & NO & NO & 21 & $73 \mathrm{~m}$ & 1959 & Lambeth & - \\
\hline New Scotland Yard & 10 Broadway & $\begin{array}{l}\text { Chapman, Taylor } \\
\text { and Partners }\end{array}$ & $\mathrm{NO}$ & $\mathrm{NO}$ & 21 & $67 \mathrm{~m}$ & 1962 & Westminster & 2017 \\
\hline City Tower & 40 Basinghall Street & $\begin{array}{l}\text { Burnet, Tait and } \\
\text { Partners }\end{array}$ & $\mathrm{NO}$ & $\mathrm{NO}$ & 21 & $69 \mathrm{~m}$ & 1957 & City of London & - \\
\hline
\end{tabular}

†Building was allowed exceptional height as a concession for funding local roadworks.

$\ddagger$ Additional floor(s) added since construction. Data represents originally constructed floor count.

Table A6: Breakdown of buildings $>100 \mathrm{~m}$ and TAs by selected city

\begin{tabular}{|l|c|c|c|c|c|c|c|c|}
\hline City & $\begin{array}{c}\text { Bldgs }>\text { 100m } \\
\text { per million } \\
\text { Population }\end{array}$ & $\begin{array}{c}\text { Total } \\
\text { Bldgs }>\mathbf{1 0 0 m}\end{array}$ & $\begin{array}{c}\text { Office } \\
\text { Bldgs }\end{array}$ & $\begin{array}{c}\text { Residential } \\
\text { Bldgs }\end{array}$ & $\begin{array}{c}\text { Hotel } \\
\text { Bldgs }\end{array}$ & $\begin{array}{c}\text { Other } \\
\text { Bldgs }\end{array}$ & $\begin{array}{c}\text { TA } \\
\text { Bldgs }\end{array}$ & $\begin{array}{c}\text { Total TA } \\
\text { Percentage }\end{array}$ \\
\hline London & 7 & 55 & 28 & 20 & 1 & 6 & 14 & 25.45 \\
\hline Chicago & 11 & 301 & 123 & 160 & 16 & 2 & 9 & 2.99 \\
\hline Houston & 40 & 88 & 60 & 19 & 3 & 6 & 5 & 5.68 \\
\hline Brussels & 15 & 17 & 15 & 2 & 0 & 0 & 0 & 0.00 \\
\hline Benidorm & 384 & 26 & 0 & 25 & 1 & 0 & 0 & 0.00 \\
\hline Sao Paulo & 20 & 231 & 75 & 142 & 9 & 5 & 1 & 0.43 \\
\hline Non-London & - & 663 & 273 & 348 & 29 & 13 & 15 & 2.26 \\
\hline Total & - & $\mathbf{7 1 8}$ & $\mathbf{3 0 1}$ & $\mathbf{3 6 8}$ & $\mathbf{3 0}$ & $\mathbf{1 9}$ & $\mathbf{2 9}$ & $\mathbf{4 . 0 3}$ \\
\hline
\end{tabular}


Table A7: Chicago Buildings Designed by TA Architects Before and After their TA Award

\begin{tabular}{|c|c|c|c|c|c|c|}
\hline Building Name & Address & Architect & TA & Floors & Height & Year Built \\
\hline The Willis Tower & 233 South Wacker Drive & Nathaniel Owings & NO & 110 & $442 \mathrm{~m}$ & 1974 \\
\hline John Hancock Centre & $\begin{array}{l}875 \text { North Michigan } \\
\text { Avenue }\end{array}$ & Nathaniel Owings & NO & 100 & $344 m$ & 1969 \\
\hline Onterie Centre & 441 East Erie Street & Nathaniel Owings & YES & 58 & $174 \mathrm{~m}$ & 1986 \\
\hline Three First National Plaza & 70 West Madison Street & Nathaniel Owings & $\mathrm{NO}$ & 57 & $234 \mathrm{~m}$ & 1981 \\
\hline One Magnificent Mile & $\begin{array}{l}\text { 940-980 North Michigan } \\
\text { Avenue }\end{array}$ & Nathaniel Owings & NO & 57 & $205 \mathrm{~m}$ & 1983 \\
\hline 330 North Wabash & 330 North Wabash Avenue & Ludwig Mies van der Rohe & YES & 52 & $212 \mathrm{~m}$ & 1973 \\
\hline Madison Plaza & 10 North Wells Street & Nathaniel Owings & NO & 44 & $182 \mathrm{~m}$ & 1982 \\
\hline The Plaza on Dewitt & 260 East Chestnut Street & Nathaniel Owings & NO & 43 & $120 \mathrm{~m}$ & 1966 \\
\hline One Financial Place & 440 South LaSalle Street & Nathaniel Owings & NO & 39 & $157 \mathrm{~m}$ & 1985 \\
\hline Harris Bank Addition II & 115 South LaSalle Street & Nathaniel Owings & NO & 38 & $155 \mathrm{~m}$ & 1974 \\
\hline Gateway Centre III & 222 South Riverside Plaza & Nathaniel Owings & NO & 35 & $137 \mathrm{~m}$ & 1971 \\
\hline 321 North Clark & 321 North Clark Street & Nathaniel Owings & YES & 35 & $155 \mathrm{~m}$ & 1987 \\
\hline $\begin{array}{l}\text { Cook County } \\
\text { Administration Building }\end{array}$ & 69 West Washington Street & Louis Skimore & YES & 35 & $145 \mathrm{~m}$ & 1964 \\
\hline Equitable Building & $\begin{array}{l}401 \text { North Michigan } \\
\text { Avenue }\end{array}$ & Louis Skidmore & YES & 35 & $139 \mathrm{~m}$ & 1965 \\
\hline Hartford Plaza South & 150 South Wacker Drive & Nathaniel Owings & NO & 33 & $126 \mathrm{~m}$ & 1971 \\
\hline $\begin{array}{l}\text { Dirksen Federal Building, } \\
\text { Chicago Federal Centre }\end{array}$ & $\begin{array}{l}\text { 219,230 South Dearborn } \\
\text { Street }\end{array}$ & Ludwig Mies van der Rohe & $\mathrm{NO}$ & 30 & $117 \mathrm{~m}$ & 1964 \\
\hline One Illinois Centre & 111 East Wacker Drive & Ludwig Mies van der Rohe & YES & 30 & $110 \mathrm{~m}$ & 1970 \\
\hline 33 West Monroe & 33 West Monroe Street & Nathaniel Owings & NO & 29 & $114 \mathrm{~m}$ & 1980 \\
\hline University Hall & 601 South Morgan Street & Louis Skidmore & YES & 28 & $103 m$ & 1965 \\
\hline Loop Transportation Centre & 203 North LaSalle Street & Nathaniel Owings & YES & 27 & $102 \mathrm{~m}$ & 1985 \\
\hline 525 West Monroe & 525 West Monroe Street & Nathaniel Owings & NO & 26 & $101 \mathrm{~m}$ & 1983 \\
\hline 33 North Dearborn & 33 North Dearborn Street & Nathaniel Owings & NO & 25 & $106 \mathrm{~m}$ & 1966 \\
\hline 676 North St. Clair & 676 North St. Clair Street & Nathaniel Owings & NO & 25 & $101 \mathrm{~m}$ & 1979 \\
\hline $\begin{array}{l}500 \text { North Michigan } \\
\text { Avenue }\end{array}$ & $\begin{array}{l}500 \text { North Michigan } \\
\text { Avenue }\end{array}$ & Nathaniel Owings & NO & 24 & $99 m$ & 1968 \\
\hline River North Point & 350 North Orleans Street & Nathaniel Owings & NO & 24 & $85 \mathrm{~m}$ & 1977 \\
\hline Gateway Centre IV & 300 South Riverside Plaza & Nathaniel Owings & NO & 23 & $98 m$ & 1983 \\
\hline Harris Bank Addition I & 111 West Monroe Street & Louis Skidmore & YES & 23 & $98 m$ & 1958 \\
\hline CDW Plaza & 120 South Riverside Plaza & Nathaniel Owings & NO & 21 & $87 \mathrm{~m}$ & 1967 \\
\hline Gateway Centre I & 10 South Riverside Plaza & Louis Skidmore & YES & 21 & $87 m$ & 1965 \\
\hline Hartford Plaza North & 100 South Wacker Drive & Louis Skidmore & YES & 20 & $74 \mathrm{~m}$ & 1961 \\
\hline Inland Steel Building & 30 West Monroe Street & Louis Skidmore & $\mathrm{NO}$ & 19 & $77 \mathrm{~m}$ & 1956 \\
\hline
\end{tabular}




\section{For Online Publication only}

\section{Appendix 4: Some Effects of TAs on Development Costs and Returns}

In Section 6 we showed the estimated value of a TA designed building in a non-HPA in the City of London using sample mean values observed from buildings in the City. These are shown in Table A8 below.

\section{Table A8 here: City of London means for relevant variables}

Kufner (2011) argues that planning applications for tall buildings in London require extra time to process and we provide some evidence in Tables A9 and A10. Although fragmentary this is consistent with this claim. There is also likely to be a substantial increase in the uncertainty of the outcome. An increase in uncertainty associated with attempting to build higher using a TA will be translated by the developer into higher risk. Developers will therefore demand a greater expected return (Mayo and Sheppard (2001). Furthermore, there may be additional planning costs when attempting to build exceptionally tall. For instance city planners generally require additional and more extensive impact assessments for tall buildings15, legal assistance may be protracted, the architect may be asked to successively redesign the proposal at various stages of the planning negotiation16, the planning authority may take additional time to deliberate17, and permission may still be ultimately refused at the local or national level (Kufner, 2011). Therefore, in order to assess the actual profit incentives for developers to hire TAs one should rescale expected returns by a discount rate commensurate with the additional planning risks and delays, and account for the additional costs of submitting a large scale development proposal to a local authority.

\footnotetext{
15 Additional assessments are: impact on TV/radio and air traffic assessment; more extensive environmental impact, sunlight and daylight assessment; wind-tunnel assessment, London views management framework assessment (LVMF) and Tower of London world heritage site assessment. These assessments require consultation with: London City airport, BAA safeguarding team, Royal Parks, Mayor of London, Surveyor to the Tower of London, Surveyor to the Fabric of St Paul's Cathedral, International Council on Monuments and Sites (UNESCO), Design Council/CABE, adjoining LPAs on development which is likely to affect land in the LPA, LPAs with Strategic Views identified in LVMF.

16 Powell (2006) for instance shows how at least 10 successive design proposals of Norman Foster's 'Gherkin' at 30 St Mary Axe were given to the City of London for review until their final approval.

17 Kufner (2011) suggests that these additional regulatory demands increase the duration of the planning approval process for tall buildings by from 1 to 2.5 years.
} 


\section{Table A9 here: Planning histories building size}

\section{Table A10 here: Planning histories building approval}

From Table A9 we see that both 'average' and 'tall’ buildings may have their initially proposed sizes either increased or decreased before final planning approval although the variation observed for 'tall' buildings greatly exceeds that for conventional ones. In Table A10, time elapsed to resolve the first planning application is perhaps the best metric for direct comparison of planning delay because once the first application has been accepted, future application approvals are generally processed more quickly 18 . Taking a look at planning application timescales, Table A10 appears to show that first applications for 'tall' buildings require between 6-18 months of additional deliberation before a decision and two of the three were ultimately decided by the Cabinet minister responsible, whereas this was true of none of the normal-sized buildings. Taken together with the additional assessment requirements noted in the body of the paper, there appear to be substantial additional costs imposed by attempting to build tall. Unfortunately these various costs are so difficult to estimate with any certainty that our building cost consultants Gardiner \& Theobald were unable to quote an expected value for them.

In addition to the planning costs and uncertainties associated with building tall there is a further possible complicating factor: the speed with which TA buildings can be let. The TA rents estimated here assume that upon sale the building will have achieved the same occupancy rate as the sample average (91 percent). Of course in reality new developments are likely to be speculative, and it is far from certain that the building will be fully let on completion. Indeed, major projects with planning permission are routinely paused or abandoned in London due to a failure to secure a sufficient number of pre-lets. Any difference in the ability of average compared to tall buildings to secure first tenants and then become fully-let may further offset apparent economic rents and so reduce actual profits19.

\section{Table A11 here: Planning history lettings}

\footnotetext{
18 Private communication with City of London Planning Authority to whom we are grateful for supplying this data.

19 For instance, ‘The Shard’ 32 London Bridge didn’t secure its first office tenant until nearly 10 months after its opening.
} 
We look at this - at least for this small sample of buildings - in Table A11. We see that, unsurprisingly, the bespoke (built for specific occupiers) Riverbank House and 'Gherkin' achieved the fastest first and complete lettings of, respectively, the 'average' and 'tall' buildings. However it took the 'tall' 'Gherkin' 62 more months to achieve this than the 'average' Riverbank House. Looking at the non-bespoke buildings the two other 'average' buildings achieved first lettings between 4-43 months and full lettings 55-89 months before the other two 'tall' buildings. This small case study suggests that in general tall/large buildings do indeed struggle to secure full tenancy compared to their smaller counterparts.

Yet another possible way in which the employment of a TA might influence developers' expected revenues would be if TA buildings systematically conceded different rent-free periods in order to attract tenants. Note that since building sales can (and generally are) timed by developers to coincide with full occupation, rent-free concessions for space in TA-designed buildings would not necessarily show up in the sale price analysis of Error! Reference source not found.20; nevertheless such differentials would be relevant to any aspiring developer. We test this hypothesis with a sample of 17 leases from TA and 59 leases from standard buildings comprising 47 buildings altogether, and examine whether TA buildings yielded different rentfree periods in a series of hierarchical regressions. All leases in the sample contained a positive rent-free period incentive. Robust standard errors are used as White tests reject homoskedasticity. The results reported in Table A12 provide no evidence that rent-free periods vary significantly between type of architect or the amount of space leased.

\section{Table A12 here: Rent-free period regressions}

In sum, it appears that at least a substantial proportion of the additional, very conservatively estimated 'rent' needs to be set against identifiable additional costs and the additional time (618 months) and expense, incurred in obtaining planning approval for tall buildings, and the longer period required to fully let such a building (up to 140 months). Assuming the TA building could; (i) be let for rents of $£ 861 / \mathrm{m}^{2}$ per year21 discounted at $10 \%$, (ii) receive timeproportionate lettings and a 24 month additional wait to fully let the building from construction

\footnotetext{
20 Note that it is superfluous to test for increased rents in TA buildings, since any rental-price anomalies would directly translate into higher sale prices, which were not observed in Table 6.

21 Source: Gardiner \& Theobald. This assumption yields annual rents for our hypothetical 8-floor SA and 22floor TA building of $£ 9 \mathrm{~m}$ and $£ 27 \mathrm{~m} /$ year (including the TA-premium), respectively, if fully let.
} 
start (taking a total of 48 months), and therefore sell it, and (iii) interest rates of 10 percent; the net cost to the developer of this slower take-up would be the difference in the gain in total rental payments over the longer letting period of $£ 32 \mathrm{~m}$, and the cost in additional interest payments on the construction loan of $£ 41 \mathrm{~m}$. Net, therefore, this letting delay costs the developer $£ 9 \mathrm{~m}$. These results are summarized in Table A13 below.

\section{Table A13 here: Quantifiable costs of delay}

We then must also add the unquantifiable costs associated with the required higher rate of expected return to the developer to compensate for the risky business of going down the TA route and trying to build tall rather than taking the much less risky route provided by a building of standard permitted heights. Assuming that developers cannot earn supernormal returns would suggest that these 'unquantifiable’ costs are equivalent to as much as $£ 149 \mathrm{~m}-£ 9 \mathrm{~m}$, or $£ 140 \mathrm{~m}$.

The estimates of surpluses, economic rents, and deadweight losses in Section 6 were calculated by comparing the estimated costs and sale prices of SA and TA buildings. Surplus-maximizing building heights of SA and TA buildings were estimated through iterative calibration.

Table A8: City of London means for relevant variables

\begin{tabular}{|l|c|}
\hline \multicolumn{1}{|c|}{ Variable } & Values assumed \\
\hline Modern TA & e† \\
\hline Within HPA & $1 \neq$ \\
\hline Listed & 1 \\
\hline Office Permission Refusal Rate & $0.44 \%$ \\
\hline Employment Density 600m & 93,388 \\
\hline Listed Building Density & 2,144 \\
\hline Above Ground Floors & $8 / 22$ \\
\hline Office Space Grade A & $\mathrm{e}$ \\
\hline Percent Occupied & $91 \%$ \\
\hline
\end{tabular}

$\dagger \ln (\mathrm{e})=1$, i.e. the dummy variable is indicated in $\log$ form.

$\ddagger \ln (1)=0$, i.e. the dummy variable is not indicated in log form.

Table A9: Planning histories building size

\begin{tabular}{|c|c|c|c|c|c|c|c|}
\hline Building & Address & TA & $\begin{array}{l}\text { Initial Floors } \\
\text { Proposed }\end{array}$ & $\begin{array}{l}\text { Final Floors } \\
\text { Accepted }\end{array}$ & $\begin{array}{l}\text { Initial } \\
\text { Floorspace } \mathbf{m}^{2} \\
\text { Proposed }\end{array}$ & $\begin{array}{l}\text { Final } \\
\text { Floorspace } \mathbf{m}^{2} \\
\text { Accepted }\end{array}$ & $\begin{array}{l}\text { Percentage } \\
\text { Floorspace } \\
\text { Change }\end{array}$ \\
\hline Clements House & 20 Gresham Street & NO & 8 & 8 & 32,396 & 32,022 & -1 \\
\hline Riverbank House & 2 Swan Lane & $\mathrm{NO}$ & 11 & 11 & 39,567 & 42,291 & +7 \\
\hline Premier Place & 2-5 Devonshire Square & $\mathrm{NO}$ & 9 & 9 & 27,000 & 23,226 & -14 \\
\hline Heron Tower & 110 Bishopsgate & $\mathrm{NO}$ & 34 & 46 & 32,516 & 42,873 & +24 \\
\hline 'Gherkin’' & 30 St Mary Axe & YES & 90 & 40 & 285,658 & 47,035 & -84 \\
\hline
\end{tabular}




\begin{tabular}{|l|l|l|l|l|l|l|l|}
\hline 'Walkie-Talkie' & 20 Fenchurch Street & NO & 42 & 36 & 91,000 & 84,913 & -7 \\
\hline
\end{tabular}

Table A10: Planning histories building approval

\begin{tabular}{|c|c|c|c|c|c|c|c|}
\hline Building & Address & $\begin{array}{l}\text { Number of } \\
\text { Applications } \\
\text { Submitted }\end{array}$ & $\begin{array}{l}\text { Number of } \\
\text { Applications } \\
\text { Approved }\end{array}$ & $\begin{array}{l}\text { Average } \\
\text { Time to } \\
\text { Decision } \\
\text { (Months) }\end{array}$ & $\begin{array}{l}\text { First Application } \\
\text { Time to Decision } \\
\text { (Months) }\end{array}$ & $\begin{array}{l}\text { Initial } \\
\text { Application } \\
\text { Consultation }\end{array}$ & $\begin{array}{l}\text { Permission } \\
\text { granted by } \\
\text { Cabinet minister } \\
\text { responsible }\end{array}$ \\
\hline Clements House & 20 Gresham Street & 3 & 3 & 10.0 & 10 & $12 / 1997$ & $\mathrm{NO}$ \\
\hline Riverbank House & 2 Swan Lane & 2 & 2 & 7.5 & 10 & $06 / 2002$ & $\mathrm{NO}$ \\
\hline Premier Place & 2-5 Devonshire Square & 5 & 5 & $2.6 \dagger$ & 4 & $02 / 1997$ & $\mathrm{NO}$ \\
\hline Heron Tower & 110 Bishopsgate & 2 & 2 & 14.5 & 22 & $07 / 1999$ & YES \\
\hline 'Gherkin' & 30 St Mary Axe & 2 & 1 & 14.5 & $16+\ddagger$ & $02 / 1996$ & $\mathrm{NO}$ \\
\hline 'Walkie-Talkie' & 20 Fenchurch Street & 2 & 2 & 13.5 & 16 & $05 / 2005$ & YES \\
\hline
\end{tabular}

†Simultaneous applications were submitted and decided concurrently.

$\ddagger$ Application withdrawn after 16 months of deliberation.

Table A11: Planning history lettings

\begin{tabular}{|c|c|c|c|c|c|c|c|}
\hline Building & Address & $\begin{array}{l}\text { Bespoke } \\
\text { Development }\end{array}$ & $\begin{array}{l}\text { Constructi } \\
\text { on Start } \dagger\end{array}$ & $\begin{array}{l}\text { Date First } \\
\text { Tenant Signed }\end{array}$ & $\begin{array}{l}\text { Months to } \\
\text { First Tenant } \\
\text { from Const. } \\
\text { Start }\end{array}$ & $\begin{array}{l}\text { Date } \\
\text { Building } \\
\text { Fully Let }\end{array}$ & $\begin{array}{l}\text { Months to } \\
\text { Full } \\
\text { Occupation } \\
\text { from Const. } \\
\text { Start }\end{array}$ \\
\hline Clements House & 20 Gresham Street & $\mathrm{NO}$ & $06 / 2006$ & $05 / 2008$ & 23 & $06 / 2010$ & 48 \\
\hline Riverbank House & 2 Swan Lane & YES & $09 / 2009$ & $10 / 2006$ & -35 & $10 / 2006$ & -35 \\
\hline Premier Place & 2-5 Devonshire Square & $\mathrm{NO}$ & $07 / 1999$ & $11 / 2000$ & 16 & $11 / 2000$ & 16 \\
\hline Heron Tower & 110 Bishopsgate & $\mathrm{NO}$ & $07 / 2007$ & $10 / 2010$ & 39 & $01 / 2016$ & $103 *$ \\
\hline 'Gherkin' & 30 St Mary Axe & YES & $07 / 1995$ & $11 / 1997$ & 27 & $11 / 1997$ & $27 * *$ \\
\hline 'Walkie-Talkie' & 20 Fenchurch Street & $\mathrm{NO}$ & $07 / 2007$ & $06 / 2012$ & 59 & $03 / 2016$ & $105 * * *$ \\
\hline
\end{tabular}

†Construction is considered to have started once demolition of the previous building commenced.

* Completed 03/2011; only 45 percent let as of 02/2013; 63 percent let as of 09/2013; 100 percent let as of 01/2016.

**100 percent effectively let through purchase of scheme by Swiss RE on 06/1998 conditional on planning permission which was then granted on $08 / 2000$.

***Completed 04/2014: construction paused between 04/2009-02/2011; 57 percent pre-let as of 09/2013, 87 percent let as of 05/2014, 98 percent let as of 09/2015, 100 percent let as of 03/2016.

Table A12: Rent-free period regressions

\begin{tabular}{|c|c|c|c|c|}
\hline VARIABLES & $\begin{array}{c}(1) \\
\text { Rent-Free Period } \\
\text { (months) }\end{array}$ & $\begin{array}{c}(2) \\
\text { Rent-Free Period } \\
\text { (months) }\end{array}$ & $\begin{array}{c}(3) \\
\begin{array}{c}\text { Rent-Free Period } \\
\text { (months) }\end{array}\end{array}$ & $\begin{array}{c}(4) \\
\text { Rent-Free Period } \\
\text { (months) }\end{array}$ \\
\hline TA Building & $\begin{array}{c}5.203 \\
(3.440)\end{array}$ & $\begin{array}{c}1.115 \\
(3.052)\end{array}$ & $\begin{array}{c}-0.442 \\
(3.033)\end{array}$ & $\begin{array}{c}-0.913 \\
(3.013)\end{array}$ \\
\hline Lease Length (years) & & $\begin{array}{c}1.467 * * * \\
(0.269)\end{array}$ & $\begin{array}{c}1.102 * * * \\
(0.249)\end{array}$ & $\begin{array}{c}1.178^{* * *} \\
(0.234)\end{array}$ \\
\hline Lease Floorspace $\mathrm{m}^{2}$ & & & $\begin{array}{c}0.000354 \\
(0.000274)\end{array}$ & $\begin{array}{c}0.000368 \\
(0.000276)\end{array}$ \\
\hline Building Depreciation & & & & 0.334 \\
\hline
\end{tabular}




\begin{tabular}{|c|c|c|c|c|}
\hline \multirow{3}{*}{ Contract Start 2003} & & & & $(0.372)$ \\
\hline & 3.734 & $10.93^{*}$ & 13.24 & 12.72 \\
\hline & (4.174) & (6.328) & (8.593) & (8.700) \\
\hline \multirow[t]{2}{*}{ Contract Start 2004} & -2.889 & 4.119 & 8.349 & 8.276 \\
\hline & $(4.446)$ & $(6.460)$ & $(8.900)$ & (8.895) \\
\hline \multirow[t]{2}{*}{ Contract Start 2005} & $10.70 * *$ & $16.13^{* *}$ & $19.03 * *$ & $18.68 * *$ \\
\hline & $(4.188)$ & $(6.586)$ & $(8.846)$ & (8.878) \\
\hline \multirow[t]{2}{*}{ Contract Start 2006} & -2.438 & 3.140 & 5.909 & 5.947 \\
\hline & (3.975) & (6.123) & (8.643) & (8.648) \\
\hline \multirow[t]{2}{*}{ Contract Start 2007} & -9.401 & -0.215 & 0.780 & 0.210 \\
\hline & (5.807) & (7.151) & (8.963) & (9.034) \\
\hline \multirow[t]{2}{*}{ Contract Start 2008} & -8.924 & 5.365 & 8.307 & 7.738 \\
\hline & (5.958) & (7.691) & (9.713) & (9.909) \\
\hline \multirow[t]{2}{*}{ Contract Start 2009} & 15.33 & $25.31 * *$ & $24.70 * *$ & $24.43 * *$ \\
\hline & (11.05) & $(10.74)$ & (10.98) & (10.98) \\
\hline \multirow[t]{2}{*}{ Contract Start 2010} & 2.714 & 13.84 & 15.22 & 13.61 \\
\hline & (5.591) & (7.167) & $(9.275)$ & (9.479) \\
\hline \multirow[t]{2}{*}{ Contract Start 2011} & -6.540 & 9.913 & 11.45 & 9.985 \\
\hline & (4.245) & (6.892) & $(9.070)$ & (9.512) \\
\hline \multirow[t]{2}{*}{ Contract Start 2012} & -1.448 & 11.01 & 13.21 & 11.57 \\
\hline & (4.125) & $(6.815)$ & (8.905) & (9.224) \\
\hline \multirow[t]{2}{*}{ Contract Start 2013} & 1.234 & $15.76 * *$ & $17.47 * *$ & 15.03 \\
\hline & (5.499) & $(6.504)$ & (8.625) & (9.288) \\
\hline \multirow[t]{2}{*}{ Constant } & $17.27 * * *$ & -9.729 & -8.693 & -9.913 \\
\hline & $(3.463)$ & $(7.561)$ & (9.113) & (9.054) \\
\hline Observations & 76 & 76 & 76 & 76 \\
\hline R-squared & 0.287 & 0.567 & 0.598 & 0.603 \\
\hline
\end{tabular}

Robust standard errors in parentheses $* * * \mathrm{p}<0.01, * * \mathrm{p}<0.05, * \mathrm{p}<0.1$

Building Depreciation $=$ the number of years between the building construction date/most recent refurb and the lease start.

\section{Table A13: Quantifiable costs of delay}

\begin{tabular}{|l|l|l|c|}
\hline & Total rents received until sale & Extra financing cost & Net quantifiable costs of delay \\
\hline 8-floor SA & $£ 8 \mathrm{~m}$ after 24months & $£ 33 \mathrm{~m} \times 10 \% \times 2$ years $=£ 7 \mathrm{~m}$ & - \\
\hline 22-floor TA & $£ 40 \mathrm{~m}$ after 48months & $£ 119 \mathrm{~m} \times 10 \% \times 4$ years $=£ 48 \mathrm{~m}$ & - \\
\hline Difference & $+£ 32 \mathrm{~m}$ & $-£ 41 \mathrm{~m}$ & $-£ 9 \mathrm{~m}$ \\
\hline
\end{tabular}

\section{References Appendix 4}

Kufner, J. (2011). Tall Building Policy Making and Implementation in Central London: Visual Impacts on Regionally Protected Views from 2000 to 2008, PhD thesis, The London School of Economics and Political Science (LSE). http://etheses.lse.ac.uk/211/

Mayo, S. and Sheppard S.C. (2001). 'Housing Supply and the Effects of Stochastic Development Control', Journal of Housing Economics, 10(2): 109-128.

Powell, K. (2006) 30 St Mary Axe: A Tower for London. Merrell, London. 